\title{
New insights on the question particle $a$ in Sardinian
}

\author{
Guido Mensching \\ Georg-August-Universität Göttingen \\ guido.mensching@phil.uni-goettingen.de
}

Received: 03-05-15

Accepted: 17-06-15

\begin{abstract}
The article analyzes the Sardinian question particle $a$ in yes/no 'special' questions. Following Obenauer $(2004,2006)$, this particle is taken to mark special interrogative clauses that cannot be answered with yes or no as they denote invitations or requests, express surprise, are biased towards an answer, or are rhetorical questions. Due to its additional focalization properties, the question particle $a$ is analysed as a head merged in $\mathrm{Foc}^{\circ}$ and moved to one of Obenauer's SpIntPs (special interrogative phrases). Furthermore, as in $a$-questions nominal constituents are obligatorily dislocated, the author argues that DPs are extracted to a functional projection beneath FocP before the remnant TP is moved to [spec, FocP].
\end{abstract}

Keywords: Sardinian; interrogative clauses; special interrogatives; particle; focus.

\section{Table of Contens}

\section{Introduction}

2. Yes/no questions in Sardinian: Some data and the state of the art 3 . The interrogative particle $a$ : The state of the art and some further perspectives
4. $A$ as a marker for special yes/no questions 5. Syntactic analysis References 


\section{Introduction}

One of the various syntactic strategies to form yes/no questions in Sardinian is a structure that involves the question particle $a$ (probably < lat. AUT, DES I,34), which has been described in previous work (Jones 1993, Mensching 2008, Remberger 2010, Floricic 2010, among others) and is illustrated in (1):
a. benis
QPART come-2sG
istasera? ${ }^{1}$
(ASIt Posada and Brunella, similar
'Do you come thi
this-evening
in Ittiri, Orgosolo and Dorgali)
b. A la faghes, custa faina?
QPART it-F-CL do-2sG this-F work-F
(Puddu 2000:664)
'Will you do this work?'

Among the known properties of this structure, which is found in the Logudorese and Nuorese varieties of Sardinian, are its incompatibility with focus fronting and negation as well as the obligatory postverbal position of the subject, if present. In addition, Jones (1993:25) observes that "this particle is used predominantly, but not exclusively, in questions which are to be interpreted as requests [...], invitations, offers, etc." The aims of this $\operatorname{article~}^{2}$ are (i) to assess the latter statement; (ii) to take into account another property that has not been considered until now, namely the frequent coexistence of clitic right dislocation (CLRD) as in (1b); and (iii) to offer an approach to a principled explanation of (i) and (ii) as well as to the other properties of $a$ within a cartographic generative framework. The main working hypotheses are as follows:

1. The question particle $a$ is related to focus.

2. At the same time, $a$ marks a question as "non-standard" (cf. the concept of "special questions," Obenauer 2004, 2006).

3. CLRD (or alternatively: CLLD) of object DPs is obligatory when $a$ is in the numeration. This must be related to the focalizing properties of $a$.

In Section 2, I provide a general overview of yes/no question marking in Sardinian. We will see that besides the structure in (1), there are several other syntactic strategies that the speakers can choose to form yes/no questions and that most of them are somehow related to focus. Section 3 introduces the state of the art of the analysis of the question particle $a$. I show that this particle is also related to focus, and I support some preceding analyses that localize $a$ in Rizzi's (1997) FocP. At the end of this section, I argue that the presence of clitic dislocation phenomena, in particular CLRD, are obligatory with DPs that occur in interrogatives introduced by the question particle $a$

1 The data stemming from the ASIt interviews (see Section 2, in particular Note 3) and from other inquiries I have done have been standardized using the orthographic conventions of the Limba Sarda Comuna (= LSC, cf. RAS 2006) for representing local varieties of Sardinian.

2 Previous versions of parts of this paper were presented at the workshops "Clause types - strategies and structures" (Nov. 14 ${ }^{\text {th }}, 2009$ ) and "Special Questions" (March 12 2010), both held at the CNRS in Paris. I am grateful to Hans-Georg Obenauer and the audience of these workshops, as well as to the audience of CIDSM 8 for their helpful comments. I would also like to thank the speakers who took part in the ASIt and other interviews, in particular Marcello Bacciu and Pierangela Calzone. Finally, I am grateful to two anonymous reviewers for their substantial advice. 
- a fact that has neither been observed nor accounted for in the literature. Section 4 focuses on the pragmatic conditions that license this question type. I argue that the analysis of a larger sample of data suggests that $a$ can only be used in non-standard yes/no interrogatives, i.e., questions which either do not expect an answer in the shape of 'yes' or 'no' or which are biased (often towards a positive answer). On the basis of the results of Sections 1-4, I propose a more elaborate cartographic analysis of representing Sardinian $a$-questions that accounts at the same time for the focus-marking property of $a$ and its function as a marker of special questions while also showing how the obligatory dislocation phenomena observed can fit into the syntactic analysis.

\section{Yes/no questions in Sardinian: Some data and the state of the art}

\subsection{Basic types of yes/no questions in Sardinian}

This section introduces the basic patterns of yes/no question formation in Sardinian and is based on the results of a series of inquiries for the Atlante Sintattico d'Italia (ASIt) undertaken in Sardinia, six of which Carolina Bacciu and I conducted in 2009. ${ }^{3}$ The map in (2) shows the ASIt localities as well as some other places mentioned during the article. Since the interrogative particle $a$ seems to be mostly limited to the Logudorese and Nuorese varieties, ${ }^{4}$ I have not considered Campidanese localities (apart from Baunei).

3 The inquiries of Posada, Baunei, and Ossi were done in written form by the ASIt team in Padova (cf. Padovan and Penello 2006). Our own interviews in Dorgali, Ittiri, Brunella, Orgosolo, and Bitti (Bitti2) were conducted using face-to-face interviews (these data have not yet been published in the ASIt database). I have not considered the (written) questionnaire of Bitti (Bitti1, by the ASIt team in Padova) in this study. Normally, only one speaker was interviewed for each location, with the exception of Dorgali and Ittiri (one male and one female speaker for each location). For practical reasons, the two speakers were interviewed together. For this article, only examples in which the two speakers agreed on a sentence were chosen. In Brunella, one male and one female speaker were interviewed independently from each other (Brunella1, Brunella2). There were no special selection criteria, apart from all speakers having the dialect at issue as a native language and being well integrated into the local community. Note that the Southern part of the Logudorese territory has not yet been explored within the ASIt initiative, but we know that interrogative clauses with $a$ are available to speakers of this area (cf. Mensching 2012a, in press). I have no information on the availability of the structure at issue in the Arborense zone, which is, in reality, a transition zone between Logudorese and Campidanese. So far, there are not enough studies on the syntax of the Campidanese varieties so as to judge if Campidanese lacks this structure altogether. There is one Campidanese example in my corpus data (cf. ex. $(30 \mathrm{~b})$ ), which suggests that the question particle $a$ is available at least in some (maybe Northern Campidanese) varieties. 
(2) Main varieties of $\operatorname{Sardinian}^{5}$ (white areas) and explored localities ${ }^{6}$

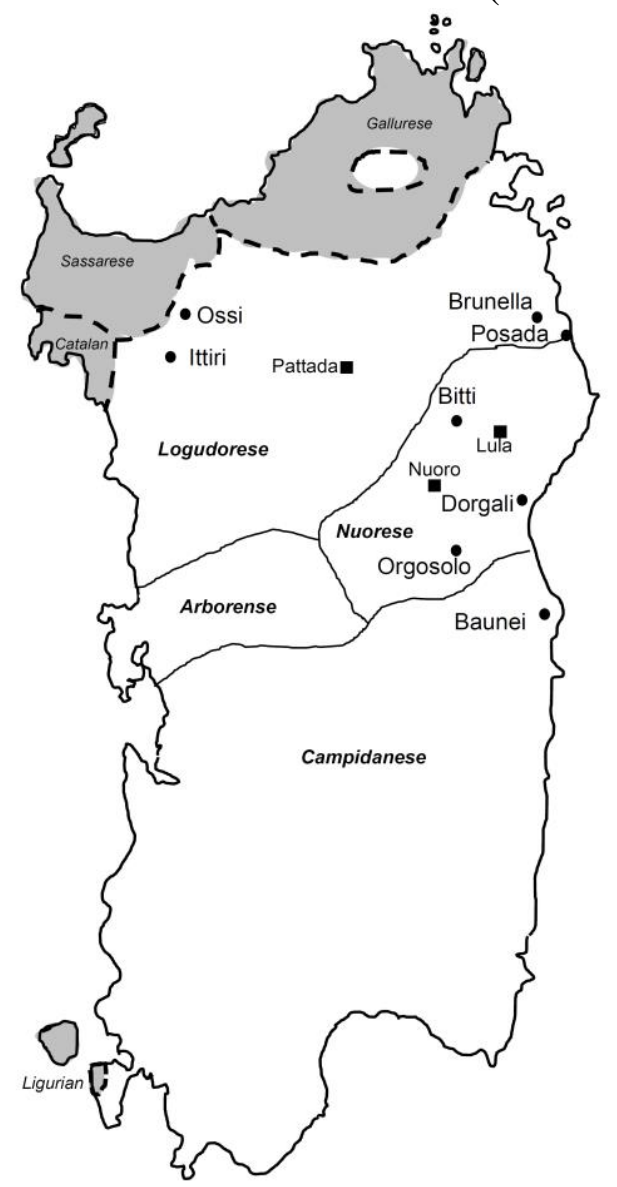
in $(3)^{7}$

The relevant trigger data for yes/no questions from the questionnaire are shown
a. Hai incontrato un bambino con i capelli rossi?
'Did you meet a redheaded boy?'
b. Vi siete ricordati di spedire la lettera?
'Have you remembered to post the letter?'
c. Vieni stasera?
'Will you come tonight?'
ASIt-Sud q. 127
ASIt-Sud q. 177
ASIt-Sud q. 209

The versions in (4) to (12) below show that Sardinian speakers can choose from different strategies for formulating yes/no questions; on some occasions the speakers offered more than one solution. At least for the Logudorese and Nuorese localities, which are under examination here, most of the different types of yes/no questions seem to follow a pragmatic rather than a geographic distribution.

$5 \quad$ Based on Virdis (1988:905). For a general introduction to Sardinian, see, e.g., Wagner (1951) reedited as Wagner (1997), Atzori (1982), Blasco Ferrer (1986), Jones (1988, 1997), and Mensching and Remberger (in press). The basic reference work for Sardinian syntax is Jones (1993), based on the variety of Lula. An overview on Sardinian syntax and morphology is provided in Mensching (in press).

6 The dots represent the ASIt inquiry points, whereas the squares are used for other localities mentioned in the article.

7 The questionnaire from Baunei only contains (3a). 
The first strategy just uses the word order of the corresponding declarative sentences (declarative sentence strategy, DSS). According to Jones (1993:24), these sentences are marked as questions "simply by means of intonation; essentially by failing to produce a full pitch descent on the syllable which bears main sentence stress."

\section{DECLARATIVE SENTENCE STRATEGY (DSS)}

\begin{tabular}{llll} 
a. As & \multicolumn{2}{c}{ intopadu unu pitzinnu chin } \\
have-2SG & met a boy with & (Posada, similar in other places ${ }^{8}$ ) \\
sos pilos rujos? & & \\
the hair-PL red-PL & sezis ammentados de imbucare \\
b. & Bos & are-PL remembered-PL of to-post \\
& you-CL-PL & (Posada, similar in other places ${ }^{9}$ ) \\
sa & litera? & \\
the & letter & (Ossi, similar in Brunella2) \\
c. & Benis & ista sero? &
\end{tabular}

Note that the speakers of some places offered versions with a clitic, which I consider a clitic right dislocation (CLRD) structure, for $(3 a, b):^{10}$
a. L' as zoviau, unu pipiu piliruju?
it-CL have-2G met a boy redheaded
b. Bos nde sezis ammentados, you-CL-PL ADV-CL are-PL remembered-PL de ch' ispedire sa lìtera?
of ADV-CL to-send the letter
(Dorgali)

As the sentences of the inquiry were presented without context, the exact pragmatic differences between the questions in (4) and those in (5) cannot be determined, ${ }^{11}$ but we can say that the former questions are "neutral yes/no questions," which focus the entire clause/event, ${ }^{12}$ whereas in the latter, the dislocated items correspond to presupposed content and are excluded from the focus.

The second strategy is the focus-fronting strategy (FFS), which has been well described in the literature (Jones 1993, 2013; Lörinczi 1999; Bentley 2009; Remberger 2010; Mensching and Remberger 2010a,b; Egerland 2013). The focus-fronted constituent can be the whole VP, an AP, an AdvP, a PP, or a DP; it is the latter in our example:

$\begin{array}{ll}8 & \text { Brunella2, Orgosolo, Ossi, Ittiri. } \\ 9 & \text { Brunella2, Orgosolo, Baunei. }\end{array}$

10 The clitic is $l(u)$ 'him' in (5'a) and $n d e$ or $n e$ in (5b), roughly corresponding to Ital. $n e$, French $e n$. The clitic in $(5 b)$ is coreferent with the PP that contains the infinitive clause 'to send the letter'. Throughout this article, I use a comma in examples containing CLRD or CLDL to separate the two prosodic/syntactic units. The comma does not necessarily indicate a pause.

11 For some hypotheses on the pragmatic conditions of the different Sardinian question types, see Remberger (2010), Jones (2013), and Vanrell et al. (2014).

12 I.e., the whole set of alternatives that can be produced on the basis of the propositions underlying the sentences. For yes/no questions within the framework of alternative semantics, see, e.g., Rooth (1992), Arregi (2007), Krifka (2008). 
(6) FOCUS-FRONTING STRATEGY (FFS)

$\begin{array}{llllll}\text { a. } & \text { Unu } & \text { piseddu } & \text { piliruju } & \text { as } & \text { imbicadu? (Brunella1) } \\ \text { b. } & \text { Unu } & \text { pipiu } & \text { piliruju } & \text { as } & \text { zoviau? (Dorgali) } \\ & \text { a } & \text { boy } & \text { redheaded } & \text { have-2SG met }\end{array}$

This structure is also found in declarative sentences with a focus on the fronted constituent. Pragmatically, we can informally say that the focused constituent in questions such as those in (6) represents a part of the proposition that is not presupposed or that the speaker is most interested in knowing the answer to; in addition, as shown by Jones (2013), they often contain "material which presents information which is particularly surprising or unexpected" (mirative focus, Jones 2013:80, cf. Cruschina 2011). ${ }^{13}$ A variant hereof is what I provisionally call the participle-fronting strategy (PFS). It is by far the most common device for yes/no question formation in Sardinian:

\section{PARTICIPLE-FRONTING STRATEGY (PFS)}

$\begin{array}{llll}\text { a. } & \text { Ammentaos } & \text { bos } & \text { seis, } \\ \text { remembered-PL } & \text { you-CL-PL } & \text { are-PL } \\ \text { a che } & \text { mandare } & \text { sa litera (Dorgali) } \\ \text { to } & \text { ADV-CL } & \text { to-send } & \text { the letter }\end{array}$

The PFS does not usually bear focus on the participle but is rather a neutral question, ${ }^{14}$ or in any case, the focus lies on the whole predicate. The PFS appears most frequently with CLRD:
a. Ammentados bos nde sezis, remembered-PL you-CL-PL ADV-CL are-PL de ch' ispedire sa lìtera? (Brunella1, Ittiri)
of ADV.CL to-send the letter
b. Ammentaos bos nde seis a che remembered-PL you-CL-PL ADV-CL are-PL to ADV-CL mandare sa lìtera? (Dorgali) to-send the letter
c. Ammentatos bos ne sezis, remembered-PL you-CL-PL ADV.CL are-PL de imbiare sa litera? (Bitti2, sim. in Ossi) of to-send the letter

(9) a. Zoviau l' as, unu pipiu piliruju? (Dorgali) found him-CL have-2SG a boy redheaded
b. Intopadu l' as, cussu/ 'unu pitzinnu piliruju? (Ittiri) found it-cl have-2sG that a boy redheaded

13 For further properties of the FFS, cf. Jones (2013:88), according to whom mirative focus on one constituent "allows the whole sentence to be taken as the information focus."

14 As Jones (2013:88) points out, the PFS can be used without any particular contextual cues or background assumptions, and would therefore be equivalent to questions with the DSS. 
Here, of course, the focus is restricted to those parts of the predicate that are not backgrounded by CLRD.

As was already observed in Mensching (2012a, in press, Mensching and Remberger in press), in some places ${ }^{15}$ the interrogative pronoun ite 'what' developed into a marker for yes/no questions (strategy with ite used as a question particle $\left.\left(\mathrm{QP}_{\text {ite }} \mathrm{S}\right)\right)$ :

\section{STRATEGY WITH ITE USED AS A QUESTION PARTICLE ( $\left.\mathrm{QP}_{\text {ite }} \mathrm{S}\right)$}

Ite as intopadu unu pitzinnu piliruju? (Ittiri)

what have-2SG found a boy redheaded

I cannot say much more about this structure, which has only recently been discovered and needs more research, but my impression is that it is rather focus neutral and geographically more restricted than the other structures.

Finally, the strategy that is the focus of this paper, i.e., the one with the question particle $a\left(\mathrm{QP}_{\mathrm{a}} \mathrm{S}\right)$, is also represented in the ASIt data. For $(3 \mathrm{~b})$, the versions given by the speakers that used this structure show CLRD:

\section{STRATEGY WITH THE QUESTION PARTICLE A $\left(\mathrm{QP}_{\mathrm{a}} \mathrm{S}\right)$}

a. A bos ne sezis ammentatos, QPART you-CL-PL ADV-CL are-PL remembered-PL de imbiare sa litera? of to-send the letter

b. A bos nde sezis ammentados, de ispedire QPART you-CL-PL ADV-CL are-PL remembered-PL of to-send sa lìtera? (Ittiri) the letter

Sentence (3c) was very often translated using this strategy. Since the Italian trigger sentence Vieni stasera? (lit. 'Do you come this evening?') often has a request reading in the sense of ('Would you like to come this evening?'), the frequent choice of the $\mathrm{QP}_{\mathrm{a}} \mathrm{S}$ may confirm the preference of this structure in questions with a request reading mentioned at the beginning of this article:

$\begin{array}{lll}\text { a. A benis } & \text { istasero? (Ittiri, sim, in many other places }{ }^{16} \text { ) } \\ \text { bPART come-2SG } & \text { this-evening } \\ \text { b. A benis } & \begin{array}{l}\text { custu sero? (Dorgali) } \\ \text { QPART come-2SG }\end{array}\end{array}$

This question type is the main subject of the present article, and its particular pragmatic conditions as well as its focus properties will be discussed in what follows.

\subsection{State of the art concerning the FFS and the PFS}

Here I briefly present the state of the art concerning two of the strategies for constructing yes/no questions in Sardinian (FFS and PPS). These structures have

\footnotetext{
$15 \quad$ Also including Campidanese varieties.

16 Bitti2, Orgosolo, Dorgali, Brunella1.
} 
deserved the most attention in the literature, and they are particularly important for the discussion of the $\mathrm{QP}_{\mathrm{a}} \mathrm{S}$ in Sections 3 to 5 because they highlight the importance of focus for yes/no question marking in Sardinian.

The FFS has been analyzed in Mensching and Remberger $(2010 a, b){ }^{17}$ by using Rizzi's (1997) split CP structure and assuming movement of an XP to [spec,FocP] and of $\mathrm{T}^{\circ}$ to $\mathrm{Foc}^{\circ}$, as shown in (13) for sentence $(6 \mathrm{~b})$ :

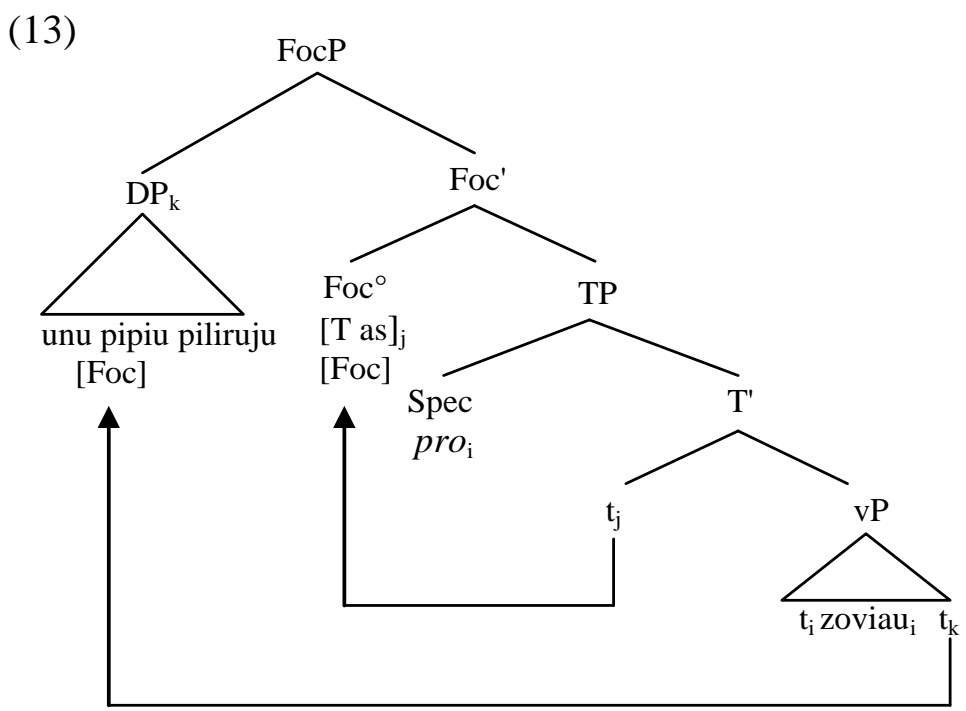

The reasons for this analysis cannot be repeated in detail here, but they involve (apart from the focus property of the fronted phrase itself) criteria such as the obligatory postverbal position of the subject (if present), incompatibility with a $w h$-phrase, and the strict adjacency between the focused constituent and the inflected verb or auxiliary. In Mensching and Remberger (2010b), we used a Rizzi-style criteria approach to explain this structure, ${ }^{18}$ as shown in (13), but one could also think of a minimalist approach, e.g., by assuming an unvalued operator feature on $\mathrm{Foc}^{\circ}$ that acts as a probe and is valued by a constituent with a feature bearing a [focus] value. As for the PFS, we argued in Mensching and Remberger (2010b) that standard tests such as those proposed by Müller (1998) suggest that it is best analyzed by remnant movement of a VP (or vP) containing only the participle to the same position, [spec,FocP]:
a. Arrivatu est a sa festa ?
Arrived is to the party
'Has he arrived at the party?'

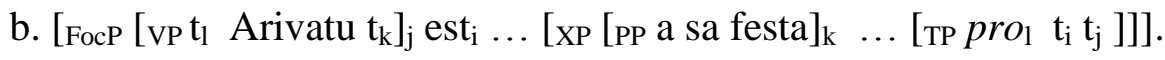

Both the FFS and the PFS are shared by declarative and interrogative clauses. This can be superficially explained by the fact that the left peripheral FocP can host several types of focus in Sardinian, such as information focus and contrastive focus, but

$17 \quad$ Also cf. Jones (1993), Mensching (2008), Remberger (2010); see an alternative analysis in Jones (2013).

18 In particular, the Focus Criterion according to Brody (1990), also cf. Puskás (2000:73):

a. A FOC Operator must be in a Spec-Head configuration with $\mathrm{X}^{\circ}[+\mathrm{FOC}]$;

b. An $\mathrm{X}^{\circ}[+\mathrm{FOC}]$ must be in a Spec-Head configuration with a FOC Operator. 
also question focus, by which Mensching and Remberger (2010b) understand narrow question focus in contrast to "neutral" yes/no questions (cf. King 1997): "The term Q(uestion) FOC(us) is used to indicate the role which corresponds to the focus in the answer of the question" (King 1997, fn. 2). This probably explains the strong preference of speakers of these structures in yes/no interrogatives and, technically, may be captured by a mechanism through which the fronted-focus constituent can check the [Q]-feature in yes/no questions; see Mensching and Remberger (2010b) and Jones (2013) for possible implementations (also cf. Section 5).

What is important here and must be kept in mind for the analysis of the particle $a$ in the next section and in Section 5 is that in the PPS and the FFS, the activation of [spec,FocP] is an important factor in Sardinian yes/no questions. The same can be said for the $\mathrm{QP}_{\text {ite }} \mathrm{S}$, if we assume that the element ite still has the same position as the whelement that it is derived from (the pronoun 'what'), which would be in [spec,FocP] according to Rizzi (1997) and further cartographic work. The DSS in (4) does not seem to have the focus property, but an analysis of further examples would show that there is a clear tendency to use CLRD structures in sentences with the DSS, as can also be found in our data in (5). This means that the constituents represented by the clitic are defocalized, which in turn indicates that the predicate without these constituents is focalized. The tendency to use CLRD structures is shared by most of the other the other yes/no question types that we have seen. This effect, which is not exclusive to questions, is interpreted by Jones (1993:356) as a structure in which "exclusive focus on the verb is achieved by right-dislocation of the object." Because the explanation of the DSS and most of the other types is outside the scope of this article, I will not discuss this in greater depth and instead turn to the analysis of the question particle $a$, where we will also continue the discussion of the CLRD phenomena.

\section{The interrogative particle $a$ : The state of the art and some further perspectives}

The basic properties of the particle $a$ are described by Jones (1993:24-25), who characterizes this item as "an interrogative particle [...] which can be prefixed to yes/no questions under certain conditions." He interprets $a$ as a complementizer "in the sense that it occurs under the COMP node [...], though it can only introduce main clauses" (1993:24). The hypothesis that $a$ is a C element is supported by the properties illustrated in (15):

a. *Cun chie a ses bènnidu?
with who QPART are come
'With whom have you come?'
*A su duttore as histu? (Jones 1993:334)
QPART the doctor have-2SG seen
Did you see the doctor?'
*A telefonatu at Juanne? (Jones 1993:25)
QPART phoned has J.
'Did J. call?'

As these examples show, the question particle $a$ is incompatible both with whitems (cf. (15a)) as well as with the FFS (cf. (15b)) and the PPS (cf. (15c)). Since the $w h$-items and focus-fronted elements (including participles) sit in COMP according to the older generative framework used by Jones (1993), his argumentation that the 
question particle is also located in COMP is straightforward. Jones also notes that the $\mathrm{QP}_{\mathrm{a}} \mathrm{S}$ is ungrammatical with negation and a preverbal subject is excluded (when present, the subject must be postverbal):

a. A no' est arrivatu Juanne? (Jones 1993:25)
QPART not is arrived J.
'Didn't J. arrive?'
*A Juanne bi venit? (Jones 1993:26)
QPART J. ADV-CL comes
Does John come here?'
A. A bi benit Juanne? (Jones 1993:24)
QPART ADV-CL comes J.

Because of the incompatibility with negation, Remberger (2010:576-578) assumes that the particle $a$ is a positive polarity marker, in the same way as no is a negative polarity marker, but with an obligatory [Q]-feature. In her theory, both the negative item no and the particle $a$ are clitics that adjoin to T (containing the verb after movement), and thus the postverbal position is explained. After incorporating $a$, the complex $\mathrm{T}$ head moves to $\mathrm{C}^{\circ}$. Apart from the facts concerning negation, Remberger argues that if $a$ were the Foc-head itself, V-movement (which is needed anyway to explain the postverbal subject position) would result in the wrong order if we want to avoid right adjunction. As an alternative, Remberger (2010:575) elaborates on an account proposed by Mensching (2008), according to which both $a$ and the finite verb are in the FocP, with $a$ occupying its specifier and $\mathrm{T}$ (containing the verb) its head after movement. As we have seen at the end of Section 2 that most types of yes/no questions are somehow focus related, I think that the latter analysis should be the preferred solution. Also note that both the PPS and the FFS are also excluded with negation, so it rather seems like a restriction to some focus types in Sardinian. Therefore, in what follows I provide some further arguments for the idea that $a$ is located in the FocP, presumably in its specifier (for now, but see Section 5).

As for yes/no questions in general, Rizzi (2001) assumes an interrogative phrase, located between ForceP and FocP, as illustrated in (17). His ideas on how yes/no questions work in Italian are illustrated in (18).

Split-CP with IntP (Rizzi, 2001, also cf. Cruschina 2007)

\section{FORCE (TOP*) INT (TOP*) FOC (TOP*) FIN}

According to Rizzi, a yes/no question comes with a [Q] feature on T, whereas the specifier of IntP hosts an empty question operator ([Q-op] in (18)), so the configuration after movement of $\mathrm{T}^{\circ}$ to $\mathrm{Int}^{\circ}$ fulfills a kind of [Q] criterion. 
(18) Italian (Arriva Gianni?)

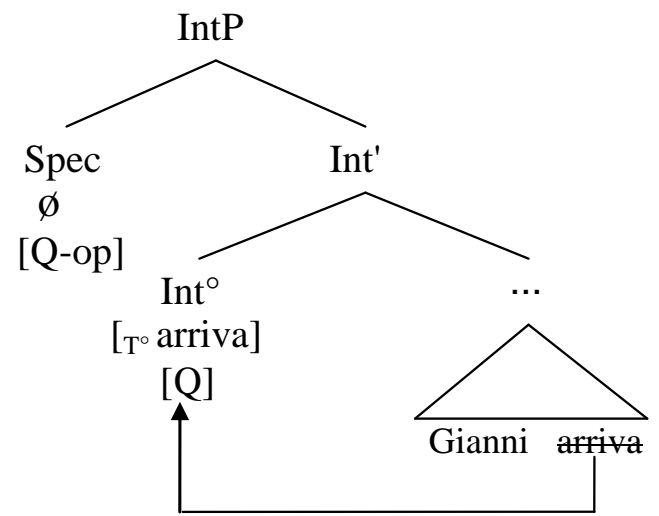

On the basis of (17), Cruschina (2007) argues that $\mathrm{Int}^{\circ}$ is the position of chi used as a question particle in Sicilian, as he shows by the following tests (also cf. Cruschina 2011):
a. Chi a MARIA salutasti?
QPART DOM M. greeted-2SG
'Was it to M. that you said hello?'
b. A Maria chi a salutasti?
DOM M. QPART her-CL greeted-2SG
'Did you say hello to M.?'
c. Chi sulu Salvo ci veni (preverbal subject
QPART only S. ADV-CL comes after QPART)
a festa?
to-the party
'Is it only S. who's coming to the party?'
d. Chi subbitu am' a partiri? (other preverbal
QPART at-once have-1pl to leave elements possible
'Do we have to leave at once?' after QPART)

(QPART before left peripheral

The item chi is located before the focus-fronted phrase in (19a), which arguably sits in the focus phrase of the structure in (17). In (19b) it appears after a clitic left dislocated phrase, the position of which must therefore correspond to the upper TopP in (17). This motivates the assumption that the question particle is situated in the IntP. Examples $(19 \mathrm{c}, \mathrm{d})$ show that the subject is preverbal and that no adjacency between the verb and the particle is required, so obviously no verb or $\mathrm{T}$ movement to the left periphery has occurred. If we apply the same tests to Sardinian, we see that almost all of them turn out to be negative:

(20) a. (*QPART before left peripheral focus)

*A a MARIA as saludadu?
QPART DOM M. have-2SG greeted
'Was it to Maria that you said hello?'
(*QPART after left peripheral focus)
*A MARIA a al as
DOM M. QPART have-2SG greeted


b. (QPART after CLLD)

A Maria, a l' as saludada?

DOM M. QPART her-CL have-2SG greeted

'Did you say hello to Maria?'

b.' $\quad$ (* QPART before CLLD)

*A a Maria, l' as saludada?

QPART DOM M. her-CL have-2SG greeted

'Did you say hello to Maria?'

c. (*Preverbal subject)

*A (solu) Salvu bi benit a sa festa?

QPART (only) S. ADV-CL comes to the party

'Does (only) Salvo come to the party?'

d. (*Other preverbal elements)
*A luego amus a tucare?
QPART at-once have-1PL to leave

'Do we have to leave at once?'

The only aspect in which Sardinian behaves similarly to Sicilian is the possibility of a clitic left dislocated item (cf. (20b)), which obligatorily occurs to the left of the particle (cf. (20b'). Examples (20a, a.', c) reconfirm the incompatibility of the particle $a$ with focus fronting and a preverbal subject. In fact, as (20d) suggests, there is an adjacency condition for the finite verb and the particle. The postverbal subject position indicates verb movement to the left periphery, as already pointed out by Jones (1993) and Remberger (2010), and the adjacency can best be modeled by assuming that both $a$ and the finite verb are located within the same phrase, logically FocP. The idea that $a$ is located in a specifier position ([spec,FocP], cf. Mensching 2008) is supported by parallel cases in other languages (cf. Remberger 2010:574; e.g., English whether and Polish czy, see Kayne 1991, Cheng 1997). Focus-fronted items, wh-elements, and the question particle $a$ thus compete for the same position, [spec, FocP] (cf. Remberger 2010:566).

Summarizing the results of Sections 2.2 and 3 thus far, based on Rizzi's (2001) criterial approach for yes/no questions, all three types (and probably also the $\mathrm{QP}_{\text {ite }} \mathrm{S}$ ) can hence be held to function in a similar way: ${ }^{19}$

Principal yes/no question configuration in Sardinian

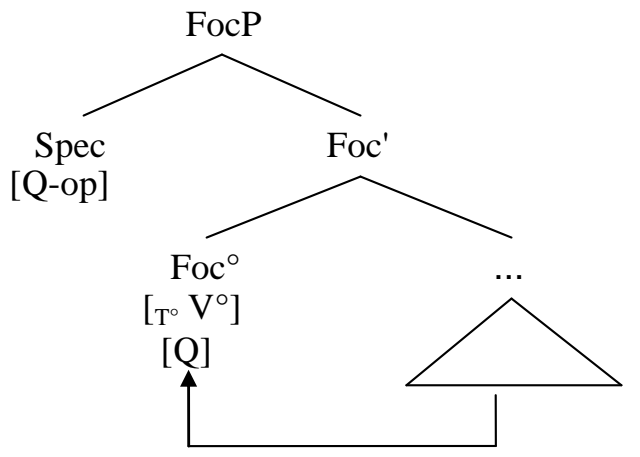

Where [Q-op] can be:

1. the particle $a$

2. the particle ite

3. a focus fronted XP ("question focus")

4. a participle in a focus-fronted VP/vP after remnant movement

19 IntP thus neither seems to be involved in Sardinian question marking with the particle $a$ nor in the fronting strategies FFS and PPS. 
Remberger's (2010) alternative analysis, according to which $a$ is mainly a polarity operator, can explain the incompatibility of $a$ with negation, but the other analysis that I have elaborated on here has the clear advantage of subsuming the $\mathrm{QP}_{\mathrm{a}} \mathrm{S}$ under a more general schema. I will therefore assume that the incompatibility with negation is rather a semantic property of some types of focus marking in Sardinian and not a particular property of the particle $a$. Since this aspect is thus beyond the scope of this article, I refer the reader to Remberger (2010) and Floricic (2010) for his concept of "focus clash," i.e., a semantic incompatibility of some focus types or elements with negation:

The interrogative particle $a$ and the fronting strategy basically work at the level of the predication as a whole, and not at the level of one of its constituents. Now, this is equally the case with the negation particle no, which explains their incompatibility. (Floricic 2010, English translation by Remberger 2010:570)

A final point that has not been sufficiently considered in the literature is the presence of a clitic in the interrogative sentences introduced by the particle $a$. According to Jones (1993:357),

there is a general tendency in yes/no questions to adopt a (non-canonical) formulation which shifts main stress to an early position in the sentence, [...] as in the right dislocated example (136):

(136) (A) l'as telefonatu, a su duttore?

Although Jones is right in qualifying this behavior as a general tendency in yes/no questions (as we have also seen in Section 2), it must be said that the $\mathrm{QP}_{\mathrm{a}} \mathrm{S}$ is the only yes/no question construction in Sardinian in which CLRD, at least of object DPs, is obligatory (unless CLLD has occurred as in (20b)). ${ }^{20}$ This is shown in the examples in (22) (based on the inquiry of four speakers): ${ }^{21}$
a. $\quad *$ A ischis
sa
beridade?
QPART know-2SG
the
'Do you know the truth?'

Jones (1993) presents a few examples with direct objects in which CLRD or CLLD has not occurred. The speakers known to me do not support these structures. It might be that the speakers at Lula (the place where Jones's speakers come from) and maybe some other places have a different grammar; however, this is not investigated here.

CLRD or CLLD (though frequent) do not seem to be obligatory with the FFS and the PPS; for the latter, see the following examples in addition to (6a):

(i.) a. Intendende sezis ite narada? (Archivi del Sud 1996:73)

hearing are-2PL what says

'Are you hearing what he says?'

b. Liggiu as sa proposta

read have-2SG the proposal

de su presidente Carai? (Sa-Limba 1999-2005)

of the president $\mathrm{C}$.

'Did you read the proposal by President C.?' 


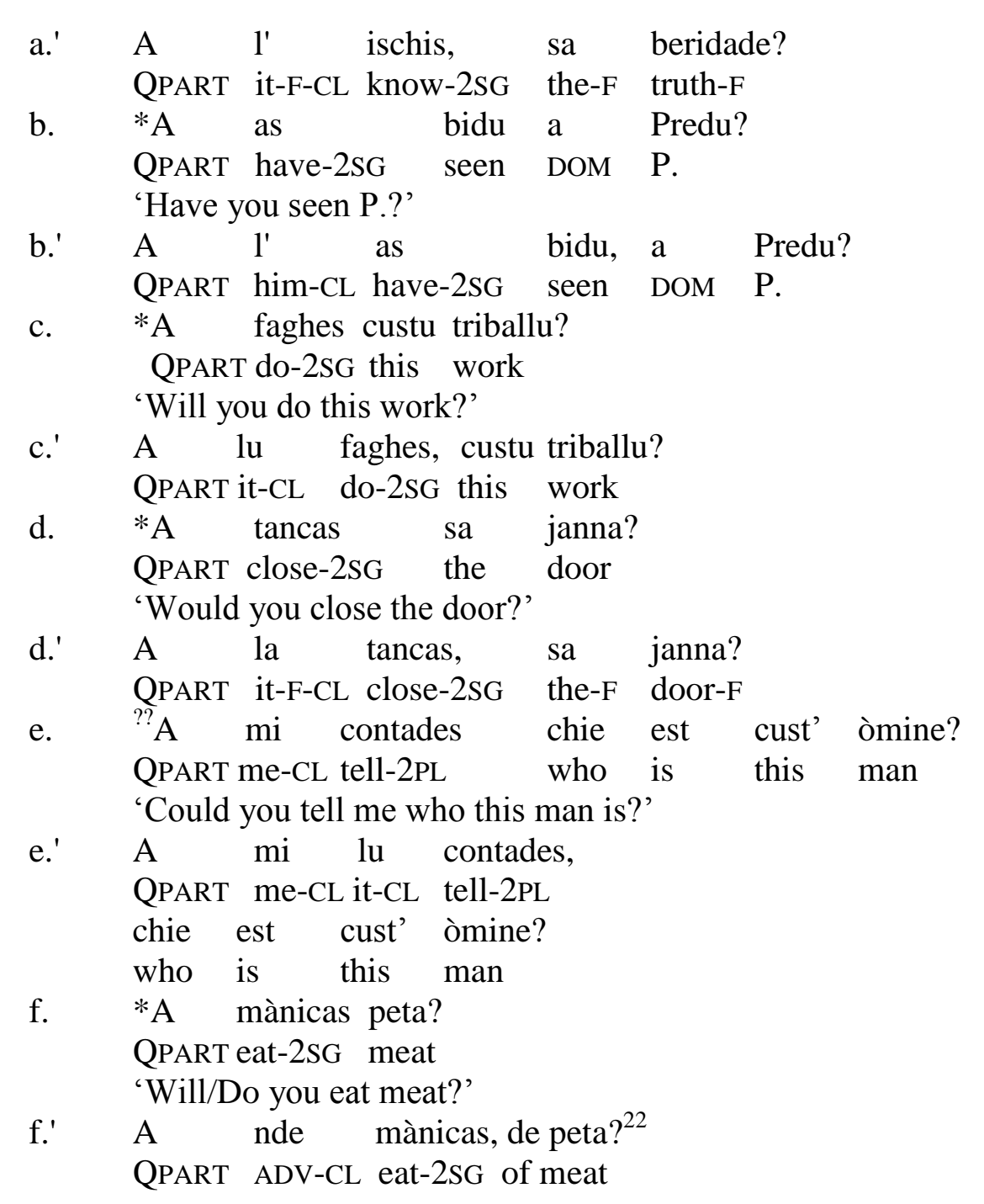

Jones (1993:358) and Remberger (2010:577) stipulate that $a$ focuses the whole predicate (VP) or the whole proposition (TP), respectively. However, the evidence from (22) suggests that only the verb is focused in these examples, and other potential (at least nominal) foci within the predicate or proposition must be explicitly defocused. In other words, it seems that $a$ does not bear any potential nominal focus constituents within its scope; such constituents must be removed and defocused (backgrounded), which is usually done by CLRD. ${ }^{23} \mathrm{I}$ am able to show this for (mostly) nominal constituents. All of them are argumental, so we might consider whether this restriction really concerns nominal or argumental phrases. There is one rather clear case of a nonnominal (e.g., prepositional) argument in my data (ex. (26e) below), which suggests that nominal is the correct characterization, but more examples are needed to ultimately decide on this issue.

22 Bare NPs must be introduced by the preposition $d e$ and are resumed by $n(d) e$ when they undergo CLRD, cf. Jones (1993:17), Mensching (2005:94-96), Mensching and Remberger (in press).

23 Whereas similar particles in yes/no questions in other languages seem to require that the interrogative operator or particle take narrow scope over a focalized individual constituent (which also leads to backgrounding of other constituents, cf. Cruschina 2011), the problem with Sardinian $a$ is that it seems to have scope over the whole predicate or proposition, from which nominal material must be removed by dislocation. 
I will return to the dislocation phenomena in Section 5, but first another fundamental property of the question particle $a$ must be considered.

\section{4. $A$ as a marker for special yes/no questions}

As Jones (1993:25, 358) has pointed out, $a$ favors a request interpretation. The aim of this section is to demonstrate that this formulation is too weak. As I shall show, $a$ is never used in standard yes/no questions but always marks a non-standard or "special" question. A standard yes/no question is a question for information that seeks a clear answer ('yes' or 'no') and usually presupposes that the speaker does not know the answer. ${ }^{24}$ I will tentatively refer to special yes/no questions as questions that do not have these properties, e.g., because they are invitations or requests, rather than asking for information or solicit agreement. I also include under this cover term rhetorical questions (the answer of which is already known to the speaker) and questions in which "there is a speaker bias towards one of the two or a speaker expectation of a different answer altogether" (Bartels 1999:131, following Bolinger 1978). Some types mentioned (in another context) in Bolinger (1978) and that we find in Sardinian $a$-interrogatives are questions that embody an invitation, questions that convey surprise at a self-evident fact, or questions that serve to pass information from speaker to hearer. ${ }^{25}$ It is important to note that, according to Obenauer's $(2004,2006)$ definition, "special question" is a term that involves both pragmatics and syntax or morphology. This means that an interrogative clause only qualifies as a special question in Obenauer's sense if it is syntactically marked as such. What I will try to show in this section is that the Sardinian question particle $a$ is such a marker.

Some evidence for the use of the particle $a$ to mark special questions comes from reactions of speakers when confronted with grammaticality tasks. To give one example, with respect to the ASIt sentence (3b), the speaker from Bitti accepted both the PFS in (23a) and the $\mathrm{QP}_{\mathrm{a}} \mathrm{S}$ in (23b):

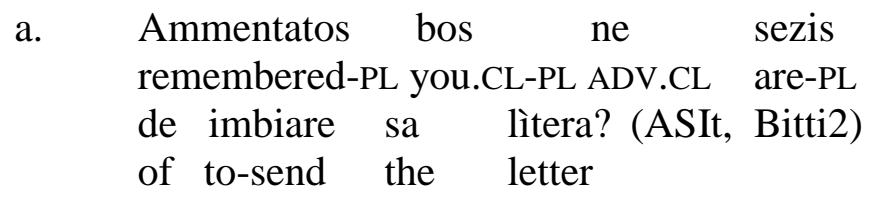

24 These are polar questions, as opposed to alternative questions, according to Krifka (2001). The latter rarely occur in Sardinian (cf. Remberger 2010:570 for an example). Alternative questions cannot have 'yes' or 'no' as an answer but require a whole sentence, see Krifkas example: "Did Mary read Die Kinder der Finsternis, or didn't she?" Answer: "She read it"/"She didnt't read it." With a special alternative question, the speaker would not expect such an answer. See Remberger's example, A l'ischides annò, chi si telefonades dae su telefono de domo, podides no pagare sas telefonadas? ('Did you know it or not that if you call from your home phone there is a possibility not to pay the phone calls?'), which probably belongs to the type of question that serves to pass information from the speaker to the hearer (see below). For further discussion, see Bolinger (1978) and Bartels (1999).

25 The term "special question" has been applied by Obenauer $(2004,2006)$ to three particular types of non-standard $w h$-questions (surprise/disapproval questions, rhetorical questions, and "I-can't-find-the-value-of- $x$ " questions) that trigger a specific syntactic behavior in some languages. Obenauer's articles leave it clear that other types of special question may exist that could be syntactically relevant both for $w h$ and yes/no questions. 


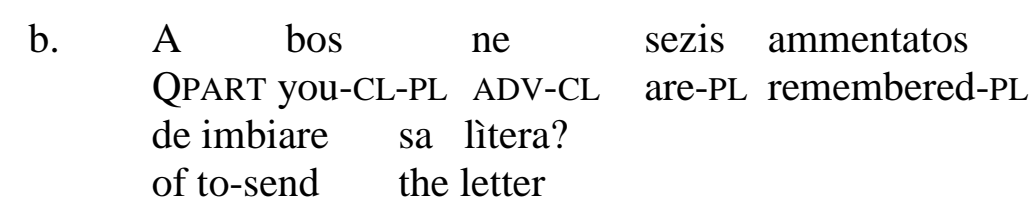

According to information provided by the speaker some months after the interview, (23a) is a true information-seeking question, whereas (23b) implies a sense of criticism: The speaker thinks that the letter hasn't been sent (i.e., it is a biased question) ${ }^{26}$

Based on such observations, I randomly collected a number of examples from different sources and classified them according to semantic and pragmatic properties concerning the question type. As a result, none of the collected examples was a pure, standard question. Instead, it turned out that we can classify all examples as one or other type of different non-standard yes/no questions, or special questions, if we adopt Obenauer's terminology. Upon the reserve that a real corpus study still remains to be conducted, the results are presented in what follows.

The first group comprises interrogatives that can be subsumed under "requests," such as polite requests, cohortatives, and invitations, as opposed to real orders, which do not seem possible with questions marked by the item $a .^{27}$

\title{
POLITE REQUESTS
}

\author{
a. A lu tuncas $^{28}$ (su barcone)? (Jones 1993:358) \\ QPART it-CL close-2SG (the window) \\ 'Would you close the window?'
}

26 Note, by the way, that this speaker does not accept the DSS, which she valued as an Italianism.

27 A real imperative meaning cannot be found with $a$ and a question intonation, but only with an imperative intonation. Cf. the following examples given to me by the speaker from Bitti:

(i.) a. A ti nch' essis dae (mesu 'e) pedes!

QPART you-CL ADV.CL. go-out from (amidst of) feet!

'Go away!'
b. A ti nche torras a domo tua!
QPART you-CL ADV.CL return-2SG to house your
'Go home!'
c. A istas mutu!
QPART stay-2SG silent
'Shut up!'

\begin{abstract}
Although the literature considers imperative $a$ as being the same $a$ as interrogative $a$, I am not sure that this is really the case. A study of $a$ as an imperative particle might show that it is a homophonous item with other properties and maybe of another origin. I will therefore not discuss imperatives in this article.



b. Aio', a m' accumpanzas
come-on QPART me-CL accompany-2SG
unu trettu? (Deledda 1982:85) ${ }^{29}$
a stretch
'Come on, do you accompany me a bit of the way?'

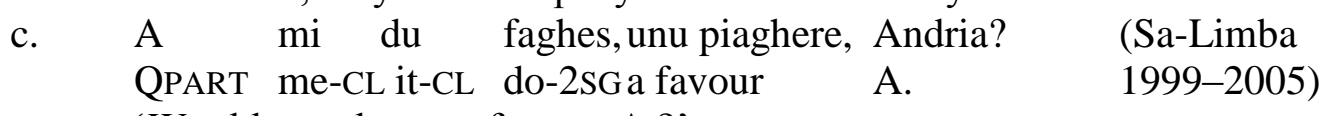
'Would you do me a favour, A.?'
d. A la faghes, custa faina? (Puddu 2000:664)
QPART it-F-CL do-2SG this-F work-F
'Will you do this work?'
e. Marie', a mi lu dasa,
Mariedda-VOC, QPART me-CL it-CL give-2SG
unu pagu 'e cicciones? (Enna 86)
a little of gnocchi ?
'Mariedda, would you give me some gnocchi?'

\section{COHORTATIVES}

(25) A giogamus a caltas? (Enna 154)

QPART play-1PL at cards

'Let's play cards!'

\section{INVITATIONS}

(26) a. A benis istasero? (ASIt, repeated from (12a))

QPART come-2SG this-evening

'Would you like to come this evening?'
b. A benis a jocare chin mecus? (Deplano, cf.
'Would you come and play with me?'
c. A keres vénnere a domo mea? (Jones 1993:25)
QPART want-2sG to-come to house mine QPART come-2SG to play with me Lörinczi 1999:105)
'Do you want to come to my house?'
d. A benies bois puru? (Deledda 1982:81)
QPART come-2PL you-PL too
'Do you come, too?'
e. A benis a binza? (Sa-Limba 1999-2005)
QPART come-2SG to vineyard
'Do you come to the vineyard'?

These different types of requests contain a verb describing the action that is requested from the addressee (in the case of cohortatives both from the addressee and the speaker). This can also apply to requests for information (cf. Kiefer 1980:97), as in (27), where the requested action is encoded in the predicate ('to tell the speaker who is Mr. Kurtz'). But the required information is normally formulated indirectly through the formula 'Do you know ...', as in $(27 b, c, d)$ : 


\section{REQUESTS FOR INFORMATION}
a. Pro praghere [...] a mi lu contat, For favour QPART me-CL it-CL tells chie est custu Tziu Kurtz? (Conrad 2002:52) who is this uncle $\mathrm{K}$.
'Please [...] would you tell me who is this Mr. K.?'
b. A l' ischides bois, inue ch' est? (Enna 106) QPART it-CL know-2PL you-PL where ADV.CL is 'Do you know where it is?' = 'Could you tell me where this place is'
c. A l' ischides bois, sa domo? (Enna 106)
QPART it-F know-2PL you-PL the-F house-F 'Do you know the house?' = 'Can you tell me where it is?'
d. Vostè, a l' ischit, inue che sunu? (Enna 156) you QPART it-CL knows where ADV.CL are-PL 'Do you know where they are?' = 'Can you tell me ...?'

The last type of this group are requests for permission. The semantics of permission are encoded in the verb 'may' (Sard. poder) in the first person. They are still requests, as they can be paraphrased by 'Would you give me the permission':

\section{REQUESTS FOR PERMISSION}
a. A mi poto sedere? (Deplano, cf. Lörinczi 1999:105)
QPART me-CL may-1SG to-sit-down?
'May I sit down?'
b. A nde potzo fàghere una còpia? (Pintore) QPART ADV-CL may-1SG make a copy 'May I make a copy of it?'

Similar to requests are offers, but they are not identical, since they are usually considered as commissive speech acts (and not directive ones like requests and invitations of the type illustrated in (24)-(28)). This type normally contains verbs such as 'want' (Sard. cherrer, bolliri):

\section{OFFERS}

(29) a. A ndi bolisi? (Sa-Limba 1999-2005)

QPART ADV-CL want-2SG

'Do you want some (of it)?'

b. A lu cheres, custu petzu de casu? (Brunella)

QPART it-CL want-2SG this piece of cheese

'Would you like this piece of cheese?'

All these types can be subsumed under the label "indirect speech acts." However, the particle $a$ cannot be considered exclusively as a device to mark questions as several types of directive and commissive speech acts. The reason is that it also appears in others type of non-standard yes/no questions. One very frequent type corresponds to 
questions that serve to pass information from the speaker to the hearer (Bartels 1999:132). In my corpus of examples, such questions are always introduced by 'Do you know', which, preceded by $a$ and the clitic $l(u)$, nearly has the character of a formulaic expression.

QUESTIONS THAT SERVE TO PASS INFORMATION FROM SPEAKER TO HEARER

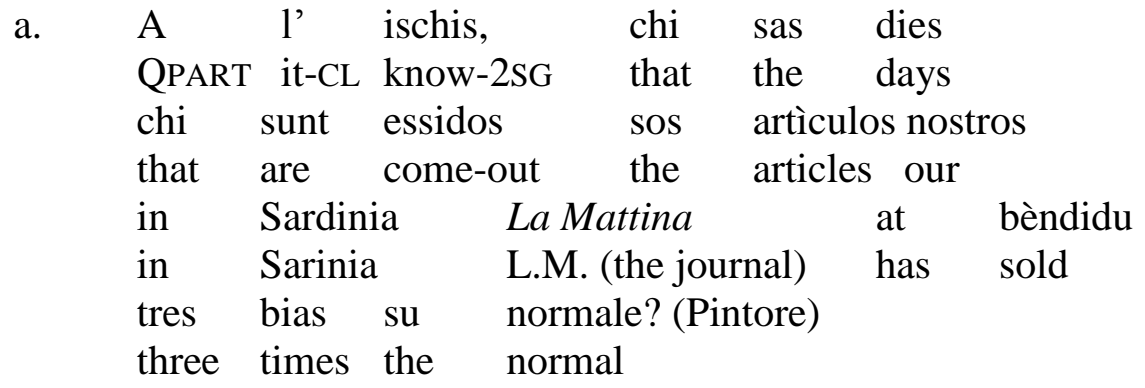

'Did you now that in the days in which our articles were published in S., (the journal) L.M. sold three times more than usual?'

b. A l' isceis ca

QPART it-CL know-2PL that

sa CUEC de Karalis hat pubblicadu

the C. of Cagliari has published

unu libru de scientia e technologia moderna

a book of science and technology modern

in limba sarda?

in language Sardinian (Sa-Limba 1999-2005)

'Did you know that CUEC at Cagliari has published a book on modern science and technology in Sardinian?'

c. A l' ischis chi su pitzinnu
QPART it-CL know-2sG that the child
chi faeddat duas limbas
that speaks two languages
est prus abbistu?
is more intelligent $\left(\mathrm{Web}^{31}\right)$

'Did you know that the child who speaks two languages is more intelligent?'

These examples are all structured in the same way: The verb 'to know' in the second-person present tense indicative is followed by a complement clause that contains the information the speaker wants to convey. There is another type, which I tentatively also subsume under this category, but in which the question only introduces the topic of the information by means of an indirect $w h$-question as a complement of the verb 'to know':

$$
\begin{aligned}
& \text { a. A l' ischis, pro itte Deus at fattu } \\
& \text { QPART it-CL know-2sG for what God has made } \\
& \text { sa notte e sa die? (Deledda 1982:70) } \\
& \text { the night and the day } \\
& \text { 'Do you know why God made night and day?' }
\end{aligned}
$$


b. A l' ischis itte at iscrittu Onida

QPART it-CL know-2SG what has written O.

Iin sa presentada de sa LSU? (Sa-Limba 1999-2005)

in the presentation of the LSU

'Do you know what O. wrote in the presentation of the LSU?'

The information itself is presented by the speaker immediately after the question. This can be illustrated for (31a) by the broader context of this sentence (I quote the Italian version of which the Sardinian is a translation and its English translation):

(32) a. Vedi, perché Dio ha creato il giorno e la notte? Il giorno per dar agio al demonio di combattere contro di noi; la notte perché possiamo raccoglierci in noi stessi e vincer le tentazioni. (Deledda 1920:76)

b. Look, why did God create day and night? The day to make it easy for the devil to fight us, the night so we can collect our thoughts and conquer temptation. (Deledda 1995:58)

Let us take this example to illustrate my argument: The fact that a question can have this function is also shared by Italian and English and is maybe universal. This belongs to pragmatics. But the important point is that Sardinian, in contrast to Italian and English, syntactically marks this interrogative as a special question by using $a$.

The question particle $a$ is also often used in biased questions (mostly but not exclusively $^{32}$ in positively biased questions). ${ }^{33}$ This can be seen immediately in (33a). Here, the speaker himself says that the objects at issue are beautiful:

\section{BIASED QUESTIONS}

a. A bos piaghent?
QPART you-PL-CL please-3PL
Bellas sunt beru? (Falconi 2003:53)
Beautiful are-PL true
'Do you like them? They are beautiful, aren't they?'
b. A la ides cussa domo in altu? (Enna 106)
QPART it-CL see-2SG that house in high
'Do you see this house up there?'
A bos l' ammentades
QPART you-PL-CL it-CL remember-2PL
a Cancalleu? (Falconi 2003:26)
DOM C.
'Do you remember C.?'

Cf. example (23b) for a negatively biased question.

Cf. Nilsenova and van Rooy (2003). Such questions are called "conducive questions" by Kiefer (1980:98): They are not neutral with respect to the expected reply, but reflect "the speaker's beliefs, expectations or emotional reactions to the previous discourse" (Wikberg 1975:124). Vanrell et al. (2014) conclude from their data that questions with $a$ are always unbiased, but note that their trigger sentences are all of the type "Can you give me X? / Do you have X?", in which the speaker hopes to obtain the object at issue. 

d. A be nd' at zente manna
QPART ADV-CL ADV-CL has people big
in domo tua? (Deplano, cf. Lörinczi 1999:105)
in house your
'Are there old people at your home?'
e. A ti nde contan contos
QPART you-CL ADV-CL tell-3PL stories
de sa zoventude issoro? (Deplano, cf. Lörinczi 1999:105)
of the youth their
'Do they tell you stories about their youth?'

In the other examples, the bias can be seen from the context. The text passage in (34) contains various repetitions of the question 'Do you see (them)?', both with the PFS and the QPART $\mathrm{S}$, whereas the Italian original uniformly uses '( $\mathrm{Li}$ ) vedi' in all four cases. $^{34}$

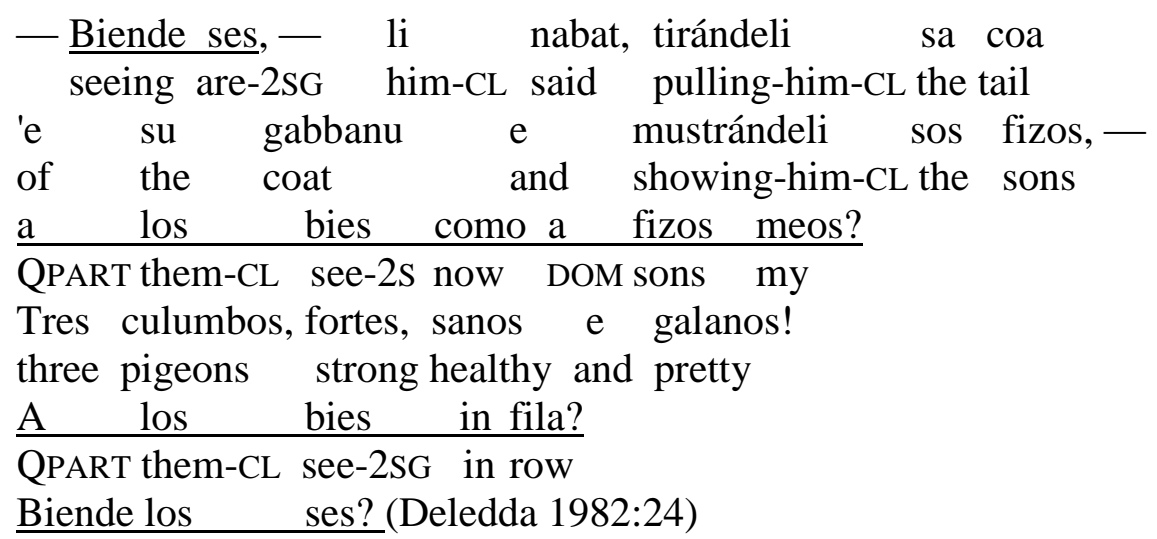

seeing them-CL are-2SG

'Look,' he shouted at him, tugging at his coat tails and motioning toward his

sons. 'See my three sons now? Three doves! And strong, eh, and healthy, and

handsome! See them standing there in a row? [...].' (Translation by Martha King = Deledda:1995:4-5)

The passage starts off with a question featuring the PFS, asking whether the addressee is seeing (the people the speaker is pointing at). Once he thinks that the addressee is seeing them, he uses the $\mathrm{QP}_{\mathrm{a}} \mathrm{S}$ to repeat the question more precisely, but note that it is biased now and serves as a kind of confirmation question. The same holds for the next question ('Do you see them standing in a row?'). At the end, the PFS is used again. We may suppose that this is because the PFS is often used for emphasis (Remberger 2010, Jones 2013).

Finally, I also found some isolated examples of questions in soliloquy and surprise questions:

34 «Vedi», gli gridava, tirandogli la falda del cappotto, e accennandogli i suoi figli, «li vedi ora i figli miei? Tre colombi! e forti, eh, e sani, e belli! Li vedi in fila, li vedi? [...]» (Deledda 1920:6). 
QUESTIONS USED IN SOLILOQUY

(35) A nos at a perdonare Deus? (Deledda 1982:148)

QPART us-CL has to forgive God

'Will God forgive us?'

\section{SURPRISE QUESTIONS}

(36) A bi ses galu innoche? (Bitti)

QPART ADV-CL are-2SG still here

'Are you still here?'

As I said, I did not find any questions of which a clear or unbiased answer 'yes' or 'no' is expected. It seems that $a$ serves to mark a considerable number of partially, not clearly connected functions. For example, we could say that $a$ in examples (24) to (28) encodes something like "rogative mood", which some languages seem to have developed as a grammatical category (cf. König and Siemund 2007), but what about the other functions? We cannot even classify $a$ as a marker of indirect speech acts, since some of the functions do not fall under the speech act distinction. An issue that cannot be answered on this occasion is the question of what functions $a$ cannot have. For example, whereas the particle is compatible with surprise questions, I have never observed $a$ in clear disapproval questions (e.g., of the type 'Are you crazy?'). Future research will show whether some common feature can be found for all these types. ${ }^{35}$ For now, I provisionally assume that the common point is that the questions introduced by $a$ are non-canonical yes/no questions. If we adopt Obenauer's concept of special questions (originally formulated for $w h$-questions) to the Sardinian yes/no questions, we can apply the following rough definition and research program formulated by Hans-Georg Obenauer:

It is generally acknowledged that besides their interpretation as 'standard' (or 'information') questions, they [i.e. interrogatives] can convey other meanings, although it remains largely unclear what 'special' question interpretations there are and where they have their sources. I argue that the syntactic structure, in particular the left sentence periphery, plays a crucial part.

Such an approach contrasts with largely shared views concerning interrogatives; thus, a common view is expressed by Siemund (2001) who sees rhetorical questions [...] as (true) "interrogatives uttered in a context in which the answer to them is given", a "non-canonical use". I want to demonstrate that there are cases - including rhetorical questions - where particular structural properties can be shown to be correlated with particular meaning types. (2006:247)

$35 \quad$ Vanrell et al. (2014:12) consider $a$ as a "mitigator or politeness marker that mitigates the request for information in neutral polar questions or gives the hearer the possibility of accepting or refusing the invitation in offers." This idea is interesting, and can cover some but not all the functions that I have shown. 


\section{Syntactic analysis}

In Section 3, I supported the view found in the literature that $a$ is a complementizer-like element, which in a cartographic approach should be located in the specifier of the leftperipheral FocP. The assumption that FocP and not IntP or other phrases in the split CP should be the relevant syntactic category for this question particle is motivated by the relevance of FocP for other Sardinan yes/no question types. But the particle $a$ is also directly related to focus, which can best be seen in the fact that CLRD (or CLLD) is obligatory for nominals that appear in interrogatives with this particle. A problem remaining from Section 3 is how to explain this property, which seems to be related to the property of $a$ to yield a narrow focus on the predicate or proposition. The dislocation facts seem to indicate that - at the same time - these structures do not allow nominal constituents to belong to the focused domain. In Section 4, I argued that, in addition to all these properties, $a$ marks special questions and cannot be used in pure informationseeking yes/no questions.

\subsection{Adaptation of the previous analysis to Obenauer's special interrogative phrase}

Let me begin with the latter property. It seems that the property of the $\mathrm{QP}_{\mathrm{a}} \mathrm{S}$ of introducing special questions cannot be directly related to the focalizing property. In fact, according Obenauer's (2004) view, there are "special interrogative phrases" (SpIntPs), which are located very high in the left periphery, above the FocP (and even above ForceP), and for which he provides evidence from several Romance varieties. The hierarchy he assumes can be sketched as follows (an adaptation from Damonte and Garzonio 2008 combined with Rizzi's 2001 structure in $(17)):^{36}$

$$
\begin{aligned}
& \text { SpIntP1 }>\text { TopP }>\text { SpIntP2 }>\text { SpIntP3 }>\text { IntP }>\text { ForceP }>\text { TopP }>\text { IntP }>\text { ToP }> \\
& \text { FocP }>\text { TopP }>\text { FinP } . . .
\end{aligned}
$$

The IntP is related to standard questions, whereas the higher SpIntPs are related to different types of special questions. The idea that there must exist more than one SpIntP is due to Obenauer's observation that the question types that he has examined (surprise/disapproval questions, rhetorical questions, and "I-can't-find-the-value-of-x" questions) do not behave in a uniform way in the languages that he has investigated.

Special question readings of different types have also been identified by Damonte and Garzonio (2008) for some Italo-Romance question particles: Northern Calabrian $c a$, Fiorentino $o$, and Fiorentino che. Their findings depend on the relative position that these particles take with respect to left dislocated items (located in the upper TopP) and are sketched in (38) (the arrow indicates movement, obligatory with Fior. che and optional with Fior. $o$; SpIntP3 does not seem to play any role for these particles):

N. Calabrian
Fiorentino
Fiorentino

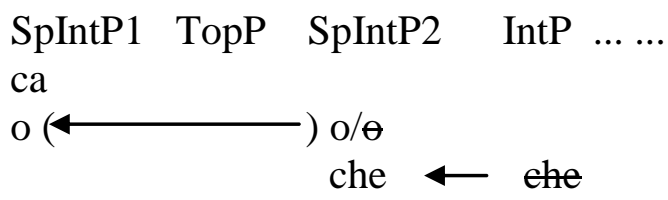

$36 \quad$ I will not consider more recent elaborations of the cartography of the left periphery (e.g., those based on Benincà and Poletto 2004), but note that all that is said in what follows could easily be adapted to these approaches. 
If we want to apply this framework to Sardinian $a$, it would seem, first, that only one SpIntP should be available in this construction, as we have no evidence of divergent syntactic behavior (e.g., with respect to the special question types determined in Section 4). Second, SpIntP1 in (37) and (38) is excluded for Sardinian because, as was shown in Section 3, a left dislocated phrase always precedes $a$. Therefore, only SpIntP2 is a possible site for the Sardinian particle. Since we cannot abandon the important insight that $a$ is strongly related to focus, we would have to say that $a$ behaves in a way similar to Fiorentino che, with the difference being that it is base-generated in FocP and not in IntP (which does not seem to play any role in most Sardinian yes/no question types, see Sections 2.2 and 3). Another difference is that, following the line of reasoning of Section 3, we have to assume that $a$ moves from the specifier position of FocP to the specifier position of SpIntP2 (instead of head movement in Fiorentino). This is shown by the tree structure in (39) for sentence (16c) (A bi benit Juanne? 'Does Juanne come there?):

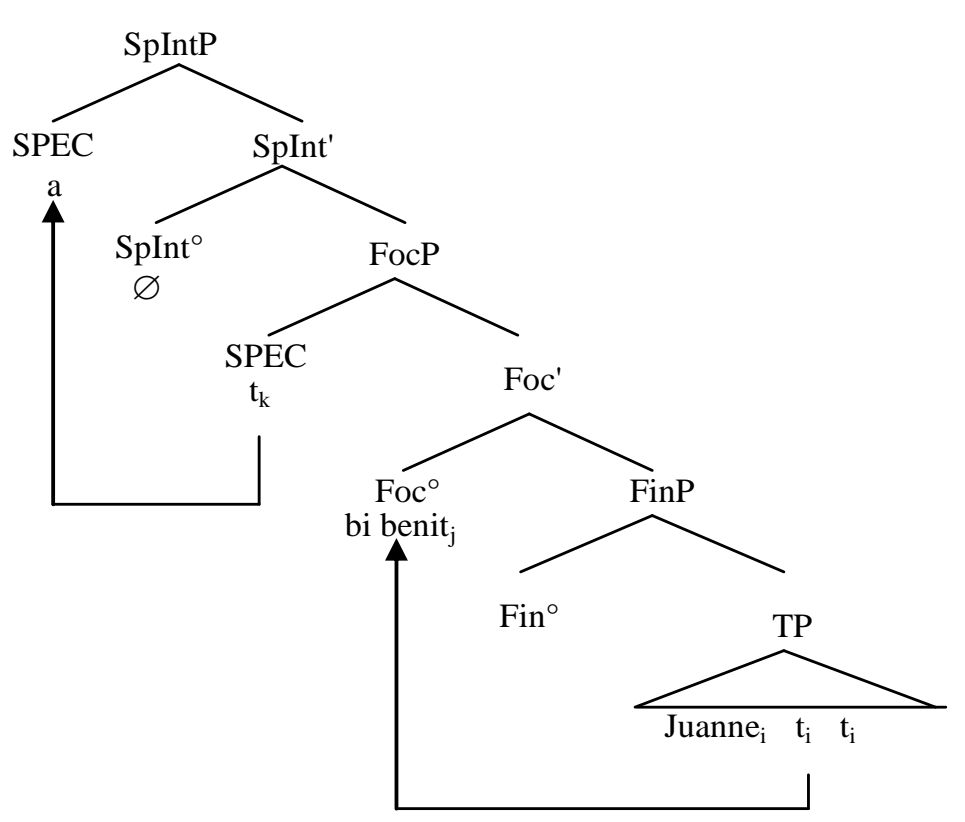

Note that such an analysis may be difficult to disprove: Since there is a strict adjacency between FocP and the finite verb, after movement of $\mathrm{T}^{\circ}$ (containing the verb) to $\mathrm{Foc}^{\circ}$, and both ForceP and IntP are probably absent from the relevant structures, we can hardly perform any tests. For the same reason, it would be hard to contradict this analysis, which may be desirable, despite all, for theoretical reasons.

\subsection{Some problems and an alternative solution}

The structure in (39) presents, however, several problems. First, since only $\mathrm{T}^{\circ}$ (containing the verb) is moved to the FocP, this analysis does not express the fact (observed in the previous literature) that the proposition (excluding dislocated items) is focused in $\mathrm{QP}_{\mathrm{a}} \mathrm{S}$ questions and not the verb alone. Second, it does not contain any explanation of why this should be the only question type in which dislocation of nominal constituents (in particular, CLRD) is obligatory in this structure. This property suggests that whenever nominal constituents occur, they cannot belong to the focus and must be removed from the part of the sentence that contains the proposition (cf. Section $3)$. 
For the first problem, what we would like to say is that in a sentence such as (26b) (A benis a jocare chin mecus? 'Would you come and play with me?') the whole $\mathrm{TP}$ is in the FocP. In this case, however, we have to abandon the idea that $a$ is in [spec,FocP], since this would now be the landing site of the TP. But note that if we follow this idea, the FocP's head position is available, since the $\mathrm{T}^{\circ}$ has moved to [spec,TP] together with the whole proposition, so the assumption that $a$ is a specifier is not necessary anymore. We can now further assume that $a$, the head of FocP, has a feature that attracts the whole TP to its specifier. This can be formalized within Comksy's (2000 et seqq.) probe-goal approach by an unvalued tense feature together with an [EPP]-feature on the head $a$, which targets the tense feature of the T head. As head movement is not possible here, the whole TP is pied-piped to [spec, FocP]. ${ }^{37}$ Let us assume that $a$ also comes with a feature [SpInt] - maybe a variant of [Q]-feature that expresses that $a$ cannot be used for standard, pure information-seeking questions. I think this would suffice in a cartographic account for SpIntP to be projected, to where $a$ subsequently moves. These ideas are illustrated in (40):

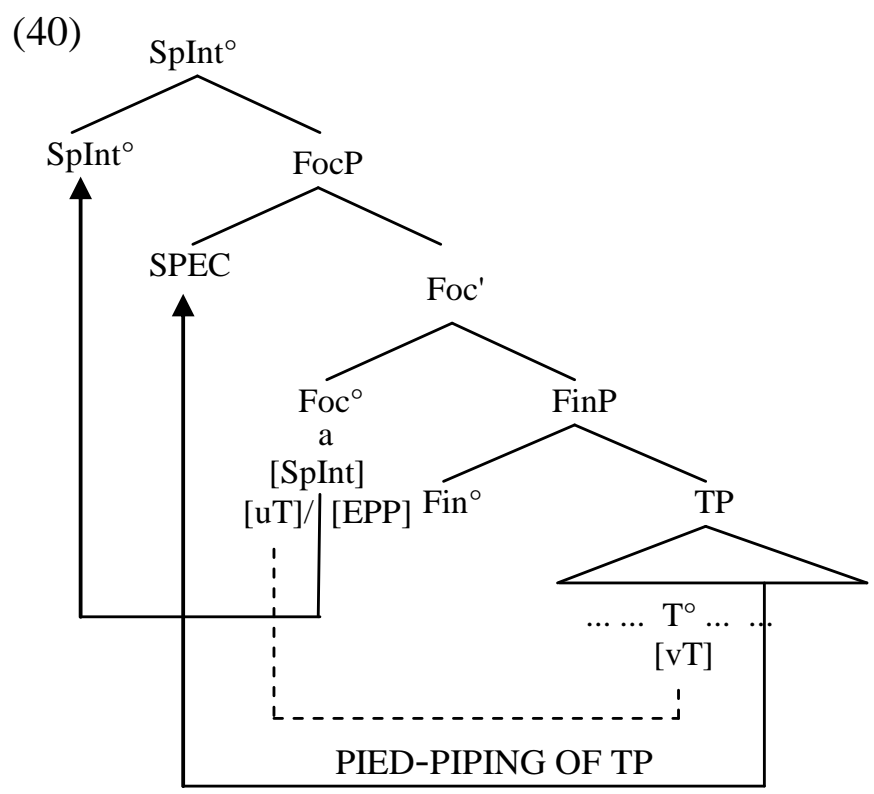

For the second problem of the analysis in (39), i.e., the question of why dislocation of some constituents within the proposition is obligatory, this analysis must be adapted by assuming that certain constituents have to be removed from the TP prior to its movement to FocP - the standard device being CLRD. Among the numerous accounts to explain CLRD, there are many that explain this phenomenon as movement processes that lead to the left periphery. This is achieved by the extraction of the dislocated constituent followed by a remnant movement operation (cf., among others, Zubizarreta 1998, Cecchetto 1999, Frascarelli 2000; see Kayne 1998 for similar ideas for other constructions). This is sketched in (41) for example (5a), which uses the declarative sentence strategy (DSS), in which dislocation is optional:

37 For pied-piping, see, among many others, Horvath (2007) and Heck (2008, 2009). 


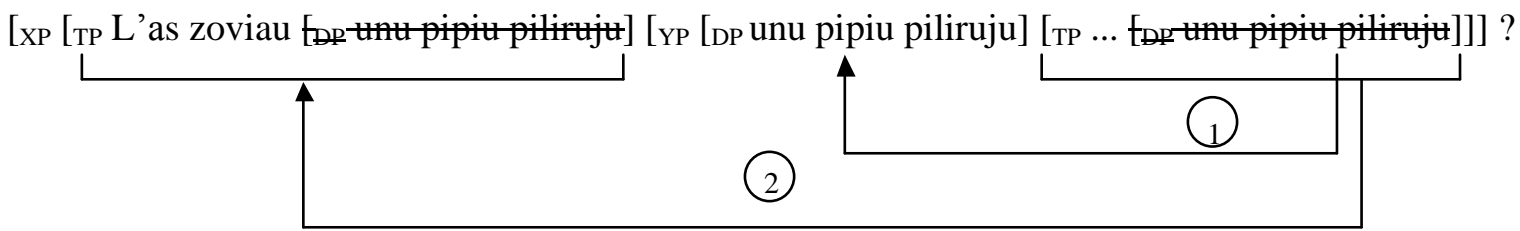

This type of account differs with respect to the landing sites of the DP and the TP. For example, Frascarelli (2000) assumes that the DP is base generated in a TopP and the TP (AgrSP in her account) moves to an FP above it. Within the framework adopted here and considering our data, what we want to assume is that the TP is in [spec, FocP], so the clitic right dislocated phrase must be in projection below it, which we may provisionally call a background phrase $(\mathrm{BgP})$. As we said, in the DSS used as an example here, this operation is optional. In contrast, when the head of FocP (which is empty in (41)) is $a$, it becomes obligatory.

We have not been concerned so far with the nature of the material that has to be dislocated. If we have a look at the data presented in Sections 1 to 4, it seems that only adverbial constituents can remain within the TP remnant: local PPs in (26c,e), a PP indicating manner in (25), and an adverbial infinitive clause in (26b). ${ }^{38}$ There are some examples that seemingly contain DPs that have not undergone CLRD - unu trettu 'a stretch' and an expression meaning 'this evening' in (12b) - but these are adverbial expressions. Real "nominal" DPs must undergo dislocation. ${ }^{39}$ It therefore seems that the content of the scope domain of $a$ must obligatorily be verbal or at least verb-related in nature. This can be formulated by a semantic constraint, along the lines that the Foc head $a$ does not bear any nominal material in its specifier. If want to implement this into the syntactic component, we would have to say that either the probe (uT, which is in fact verbal in nature) or another feature of $a$ is incompatible with nominal content within its goal (the TP). I will provisionally formalize this by assuming an additional feature $[+\mathrm{V}]$ of $a$. A lexical entry of $a$ would hence look as follows:

$$
\begin{aligned}
& a, \text { category }=\mathrm{Foc}^{\circ} \\
& {[\text { SpInt }]} \\
& {[\mathrm{uT}] \text { (probe) } /[\mathrm{EPP}]} \\
& {[+\mathrm{V}]}
\end{aligned}
$$

Before I make some additional comments, let me first show a possible detailed derivation of (1b). The remnant-moved TP in $(41 \mathrm{~g}, \mathrm{~h})$ is highlighted:

38 The item $a$ that introduces the infinitive clause in (26b) is a complementizer and not a preposition. Thus, the resumptive pronoun $b i$ cannot be used here, so ultimately we cannot decide (unless we make a prosodic analysis) whether the infinitive clause has been dislocated or not. Conversely, the item de introducing the infinitive clause in (11) is a preposition, so nde or $n e$ is a resumptive clitic. I assume for now that dislocation is optional there, but this should be re-assessed in future studies with more data of this type. In any case, the constituent is not nominal, but a PP selected by the verb $s$ 'ammentare 'to remember'.

If it is CLLD, the dislocated DP moves to the highest TopP in a structure like (37), see below. 
(43) Possible derivation of (1b) (A la faghes custa faina?)

a. merge $\mathrm{V}+\mathrm{DP}_{\text {obj. }}$ to build $\mathrm{VP}$

[vP fagh- custa faina]

b. $\quad$ merge $\mathrm{v}^{\circ} ; \mathrm{V}^{\circ}$-to- $\mathrm{v}^{\circ}$ movement

[vP fagh- [vp fagh- custa faina]]

c. merge of a clitic that adds an extra EPP feature ${ }^{40}$

[vp la fagh- [vp custa faina]]

d. merge of subject (pro); movement of $\mathrm{DP}_{\text {obj. }}$ to phase border

[vP [custa faina] pro la fagh- [vP fagh- custa faina]]

e. $\quad$ merge of $\mathrm{T}^{\circ}$ and $\mathrm{v}^{\circ}(\mathrm{V}+\mathrm{cl})$ movement to $\mathrm{T}^{\circ}$

[те [ $\mathrm{T}^{\circ}$ la fagh-] [vР [custa faina] pro fagh- [vP fagh- eusta faina]]]

f. merge of $\mathrm{BgP}$ and movement of $\mathrm{DP}_{\text {obj. }}$ to [spec, $\mathrm{BgP}$ ]

[BgP custa faina [TP la fagh-[ ${ }_{\mathrm{vP}}$ [eusta faina] pro ... [VP... ]]]]

g. merge of $\boldsymbol{a}$ in $\mathrm{Foc}^{\circ}$

[FocP $\mathbf{a}$ [BgP custa faina [TP la fagh-[ve [eusta faina] pro ... [VP... ]]]]]

h. movement of TP remnant to [spec,FocP]

[FocP [TP la fagh-[vе ... pro ... [ [vP... ]]] a [BgP custa faina] TP]

i. $\quad$ merge of SpInt ${ }^{\circ}$ and head-movement of $a$

[SpIntP $\mathbf{a}[$ FocP [TP la fagh-[vP ... pro ... [ [VP... $]]]$ a [BgP custa faina $]$ TP $]]$

At least for a strict minimalist account, there is a problem between step (40e) and (40h): In the approach just sketched, backgrounding of nominal content is a requirement of the particle $a$, but at step (40f), the derivation does not "know" that $a$ is going to be merged later on, so why should BgP be projected at all? There are several solutions to this problem. A solution that comes to mind is to suppose that the derivation crashes if $\mathrm{BgP}$ is not projected, because the $\mathrm{TP}$ does not fulfill the $[+\mathrm{V}]$ requirement of $a$, and therefore only an alternative derivation that includes $\mathrm{BgP}$ succeeds. Similarly, but more formally, we could say that $a$ c-selects for $\mathrm{BgP}$.

\subsection{Compatibility of the analysis with the data and properties of Sections 2 and 3}

Finally, we have to make sure that the assumptions made in 5.2 are compatible with the data presented in Sections 2 and 3. First, a comment on the subject is in order. For simplification, in the derivation in (43), I chose a sentence with a phonetically empty subject (pro). If we have an overt subject in Sardinian, this subject will usually move to [spec,TP] so that it would remain in a preverbal position after TP-movement to BgP. This would be contrary to the data presented in Section 2, according to which the subject is obligatorily postverbal in $\mathrm{QP}_{\mathrm{a}} \mathrm{S}$ questions. The solution lies in the fact that the subject is also nominal, so it must also be removed from the TP. ${ }^{41}$ The only thing we have to assume is that the $\mathrm{BgP}$ can be generated recursively (similar to TopPs in Rizzi's theory) so both arguments can be dislocated. ${ }^{42}$ Let me illustrate the structure of $(27 \mathrm{c})$, repeated here as (44):

$40 \quad$ See Mensching (2012b) for this idea.

41 There is still a potential problem with the adverb luego in (20d), but I assume for now that a sentence initial adverb is interpreted as focalized (i.e. as a focus-fronted item) and is therefore excluded. We could also assume that $\mathrm{T}^{\circ}$ (containing the finite verb) is left adjoined to $a$ in the Foc head, prior to movement of $\mathrm{Foc}^{\circ}$ to SpInt ${ }^{\circ}$, but I will not explore this possibility here. 


\begin{tabular}{|c|c|c|c|c|}
\hline 1 ' & ischides & bois sa & domo? & (Enna 106) \\
\hline QPART it & know-2PL & you-PL the & house & \\
\hline
\end{tabular}

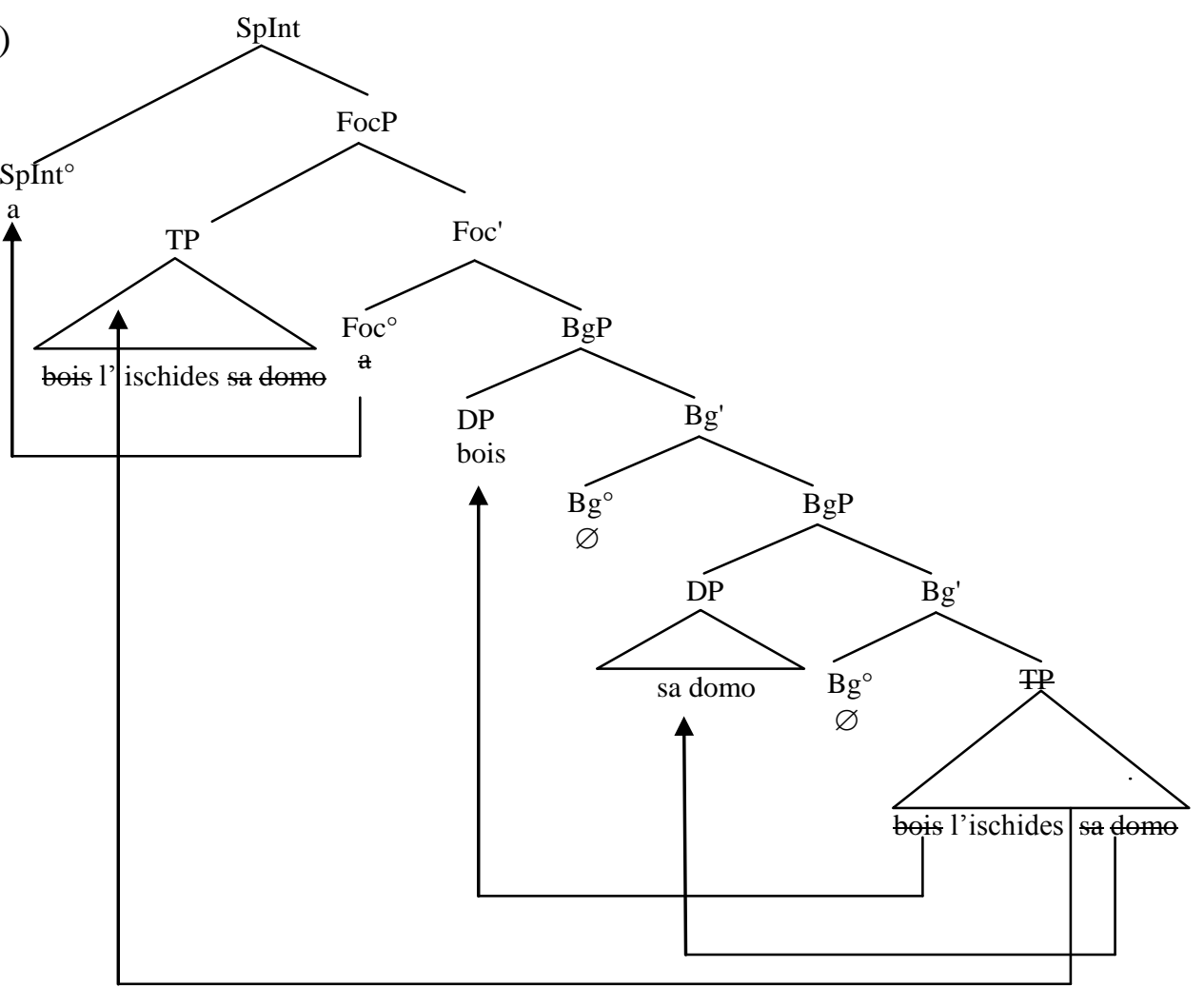

As we have seen in Section 3, clitic left dislocation is also found in structures with $a$ (cf. (20b)), and, as example (27d) shows, a subject can also be left dislocated. In both cases, the left dislocated items can be argued to make a further movement step from $\mathrm{BgP}$ to the ToP above SpIntP in the structure illustrated in (37).

How about the incompatability with the other question types, in particular the FFS and the PPS? Clearly, in (45) [spec, FocP] is occupied by the TP remnant, so that no movement of another focused constituent to this position is possible, including whphrases. Vice versa, the particle $a$, with the features as assumed in (42), cannot attract anything other than the TP.

I have already demonstrated in 5.2 how CLRD can be modeled for the DSS. In this case, a $\mathrm{BgP}$ is optionally merged if the speaker wants to intentionally background some information. For the FFS and the PFS, too, we can assume that - also as an option - a BgP can be part of the numeration. In these cases, the TP remnant, if any is left, ${ }^{43}$ can of course not be in the FocP but rather must be assumed to be in the upper one of two BgPs. ${ }^{44}$

43 Since one constituent is in [spec, FocP], $\mathrm{T}^{\circ}$ (containing the verb) in $\mathrm{Foc}^{\circ}$ and another constituent in $\mathrm{BgP}$, there is often nothing left in the TP.

44 It is important to note that the landing sites of right dislocated elements cannot be a TopP (such as Rizzi's 1997 low TopP*), because left dislocated items obligatorily precede the FocP (also cf. Mensching and Remberger 2010b:267). 


\section{Conclusions}

In the preceding pages I examined the $\mathrm{QP}_{\mathrm{a}} \mathrm{S}$ (strategy with $a$, a question particle) in Sardinian yes/no interrogatives. The literature suggests that this particle marks the predicate (Jones 1993) or the proposition (Remberger 2012) as focus. In the light of my findings and analysis, it is the latter (the proposition) - i.e., the TP in the generative framework - that is focused in these structures. In my analysis, this is yielded by the movement of TP to [spec,FocP], triggered by a probe (in Chomsky's 2000 et seqq. sense) that specifically targets the TP. The question particle $a$ itself is merged in Foc $^{\circ}$ but has to move to a functional category higher than FocP. This idea stems from a new insight of this article, namely that $a$ can only be used in non-standard yes/no questions, which I call "special questions" following Obenauer (2004, 2006), and I therefore labeled it as SpIntP (special interrogative phrase). The second new insight of this article is that nominal constituents are obligatorily dislocated in the structures containing interrogative $a$, normally through CLRD, which consists in the extraction of the relevant DP to a functional projection (that I provisionally called a background phrase, BgP) beneath FocP. This can be the consequence of a semantic property of $a$, which has to be left for future research, but which I provisionally included into syntax by means of a feature $[+\mathrm{V}]$ (as an independent feature or part of the probe). The idea behind this feature is that a proper goal of the probe can only consist of essentially verbal content (including adverbial modifiers), so that nominal categories must be removed before moving the TP to [spec, FocP] (or, in other words, only the verb and the verb-related parts of the proposition can be in a FocP headed by $a$ ).

The idea of a probe on $a$ that specifically targets the TP suffices to explain the incompatibility of the $\mathrm{QP}_{\mathrm{a}} \mathrm{S}$ with focus fronting of a single constituent, i.e., the FFS and the PFS (participle fronting), both very frequent in Sardinian yes/no questions without the particle (PPS). It also rules out $w h$-items and the simultaneous application of ite used as a question particle $\left(\mathrm{QP}_{\mathrm{a}} \mathrm{S}\right)$, as all these elements have been argued to be in [spec,FocP]. Another property of interrogatives with $a$ is the postverbal position of subjects, which was explained in previous analyses by assuming T-movement to the CP domain. In the analysis proposed here, the postverbal position of the subject is straightforwardly explained, because as a nominal constituent of the proposition, the subject must also leave the TP before the TP is raised to FocP.

Most of the different strategies of yes/no question formation in Sardinian, which have partially been explained as optional alternatives in the preceding literature, can now be distinguished. For "real" yes/no questions, the speaker can either chose a focusneutral construction (the DSS), or at least two other structures: the FFS (if a single constituent is focused) or the PFS, if the verbal action is focused (remnant movement of the VP or vP usually containing only a participle) to [spec,FocP]). The $\mathrm{QP}_{\text {ite }} \mathrm{S}$ also seems focus neutral, but because this structure has only recently been discovered (and is locally more restricted than the other strategies), more data are needed for determining how it is pragmatically distinguished from the DSS. But if the question is a special question, speakers use the $\mathrm{QP}_{\mathrm{a}} \mathrm{S}$, which then triggers the particular additional properties that I have tried to explain. 


\section{References}

Sources

Archivi del Sud 1996. Contami unu Contu. Racconti popolari della Sardegna. Vol. I Logudoro. Alghero: Archivi del Sud.

ASIt = Atlante Sintattico d'Italia (http://asit.maldura.unipd.it/, last consulted June 6th 2015).

Conrad, Joseph 2002. Coro de iscurigore (Heart of darkness). Translated by Nanni Falconi. Cagliari: Condaghes.

Enna, Francesco 1984. Sos contos de foghile. Sassari: Edizioni Gallizi.

Deledda, Grazia 1920. Elias Portolu. Romanzo. Milano: Fratelli Treves.

Deledda, Grazia 1982. Elias Portolu. Translated by Serafino Spiggia, Nuoro: Istituto superiore regionale etnografico.

Deledda, Grazia 1995. Elias Portolu. Translated by Martha King. Illinois: Northwestern University Press.

Falconi, Nanni 2003. Su cuadorzu. Cagliari: Condaghes.

Sa-Limba 1999-2005. Electronic Corpus of the Postings to the Mailing List 'Sa-Limba'. CD-ROM for internal use, Vienna/Göttingen.

Pintore, Gianfranco 2009. Sa losa de Osana. Cagliari: Condaghes.

Studies

Arregi, Karlos 2007. "Syntax and Semantics of Split Questions". In: José Camacho, Nydia Flores-Ferrán, Liliana Sánchez, Viviane Déprez, and María José Cabrera (eds.): Romance Linguistics 2006: Selected Papers from the 36th Linguistic Symposium on Romance Languages (LSRL), Philadelphia: John Benjamins, 1528.

http://dx.doi.org/10.1075/cilt.287

Atzori, Maria Teresa 1982. Sardegna. Pisa: Pacini [= Profilo dei dialetti italiani 20].

Bartels, Christine 1999. The intonation of English statememts and questions: A Compositional Interpretation. London: Routledge.

Benincà, Paola and Cecilia Poletto 2004. "Topic, Focus, and V2: Defining the CP Sublayers." In: Luigi Rizzi (ed.): The Structure of CP and IP. New York: Oxford University Press, 52-75.

Blasco Ferrer, Eduardo 1986. La lingua sarda contemporanea. Grammatica del logudorese e del campidanese. Norma e varietà dell'uso. Sintesi storica. Cagliari: Edizioni della Torre.

Bolinger, Dwight 1978. "Yes-no questions are not alternative questions." In: Henry Hiz (ed.): Questions, Dordrecht: D. Reidel, 87-105.

Brody, Michael 1990. "Some remarks on the Focus Field in Hungarian". In: UCL Working Papers, 2: 201-225.

Cecchetto, Carlo 1999. "A Comparative Analysis of Left and Right Dislocation in Romance”. In: Studia Linguistica, 53: 1, 40-67. http://dx.doi.org/10.1111/1467-9582.00039

Cheng, Lisa Lai-Shen 1997. On the Typology of Wh-Questions. New York \& London: Garland Publishing (= Outstanding Dissertations in Linguistics Series).

Chomsky, Noam 2000. "Minimalist inquiries: the framework". In: Roger Martin, David Michaels and Juan Uriagereka (eds): Step by step: Minimalist syntax in honor of Howard Lasnik, Cambridge, Mass.: MIT Press, 89-155.

Chomsky, Noam 2001. "Derivation by Phase". In M. Kenstowicz (ed.): Ken Hale. A Life in Language, Cambridge, Mass.: MIT Press, 1-52. 
Chomsky, Noam 2004. "Beyond Explanatory Adequacy". In A. Belletti (ed.): Structures and beyond. The Cartography of Syntactic Structures, Oxford: Oxford University Press, 104-131.

Chomsky, Noam 2008. "On Phases". In Carlos Otero, Robert Freidin, and Maria Luisa Zubizarreta (eds): Foundational Issues in Linguistic Theory: Essays in Honor of Jean-Roger Vergnaud, Cambridge, Mass.: MIT Press, 133-166.

Cruschina, Silvio 2007. "Marking yes/no questions". Paper presented at CIDSM 2, University of Cambridge, January 26th-27th, 2007.

Cruschina, Silvio 2011. Discourse-Related Features and Functional Projections. Oxford/New York: Oxford University Press.

Damonte, Federico and Garzonio, Jacopo 2008. "Non-standard questions and interrogative particles in some Italian dialects". Paper presented at the 18th Colloquium on Generative Grammar, Lisbon, April 17th-19th, 2008.

DES = Wagner, Max Leopold 1960-1964. Dizionario Etimologico Sardo, 3 vols., Heidelberg: Winter.

Egerland, Werner 2013. "Fronting, background, focus: A comparative study of Sardinian and Icelandic." In: Lingua 136: 63-76. http://dx.doi.org/10.1016/j.lingua.2013.07.011

Frascarelli, Mara 2000. The Syntax-Phonology Interface in Focus and Topic Constructions in Italian. Dordrecht: Kluwer.

Floricic, Franck 2010."Négation et interrogation en sarde". In: Franck Floricic and Renée Lambert-Brétière, R. (eds.), La négation et les énoncés non susceptibles d'être niés, Paris: CNRS, 101-121.

Garzonio, Jacopo 2004. "Interrogative Types and Left Periphery: some data from the Fiorentino Dialect". In: Quaderni di lavoro ASIS 4: 1-19.

Heck, Fabian 2008. On pied-piping: wh-movement and beyond. Berlin: Mouton de Gruyter.

Heck, Fabian 2009. “On certain properties of pied-piping”. In: Linguistic Inquiry 40: $75-111$.

Horvath, Julia 2000. "Interfaces vs. the computational system in the syntax of focus". In: Hans Bennis, Martin Everaert, and Eric Reuland (eds.): Interface strategy, Amsterdam: Royal Netherlands Academy of Arts and Sciences.

Horvath, Julia 2007. "Pied-piping". In: Martin Everaert, Henk van Riemsdijk, Rob Goedemans, and Bart Hollebrandse (eds): The Blackwell Companion to Syntax, Oxford: Blackwell, 569-630.

Jones, Michael Allan 1988. "Sardinian”. In: Martin Harris and Nigel Vincent (eds): The Romance Languages, London/New York: Routledge, 314-350.

Jones, Michael Allan 1993. Sardinian Syntax. London, New York: Routledge.

Jones, Michael Allan 1997. "Sardinia". In Martin and Mair Parry (eds), The Dialects of Italy. London/New York: Routledge, 376-384.

Jones, Michael Allan 2013. "Focus, fronting and illocutionary force in Sardinian". In: Lingua 134: 75-101.

http://dx.doi.org/10.1016/j.lingua.2013.07.014

Kayne, Richard 1991. "Romance Clitics, Verb Movement and PRO." Linguistic Inquiry 22: 647-686.

Kayne, Richard 1998. “Overt vs. Covert Movement”. In Syntax 1:128-191. http://dx.doi.org/10.1111/1467-9612.00006

Kiefer, Ferenc 1980. "Yes-No Questions as Wh-Questions." In: John R. Searle, Ferenc Kiefer and Manfred Bierwisch (eds): Speech Act Theory and Pragmatics, Dordrecht: D. Reidel, 97-119. 
King, Tracy Holloway 1997. "Focus Domains and Information-Structure". In: Miriam Butt and Tracy Holloway King (eds): Proceedings of the LFG97 Conference, Stanford: CSLI Publications.

[http://web.stanford.edu/group/cslipublications/cslipublications/LFG/LFG21997/lfg97king.pdf, last consulted on May $\left.3^{\text {rd }}, 2015\right]$.

König, Ekkehard and Peter Siemund 2007. "Speech act distinctions in grammar", in: Timothy Shopen (ed.), Language Typology and Syntactic Description, Cambridge: Cambridge University Press, 276-324.

Krifka, Manfred 2001. "For a structured meaning account of questions and answers". In: Caroline Fery and Wolfgang Sternefeld (eds.): Audiatur Vox Sapientiae. A Festschrift for Arnim von Stechow, Berlin: Akademie Verlag, 287-319.

Krifka, Manfred 2008. "Basic notions of information structure". In: Acta Linguistica Hungarica 55: 243-276.

Lörinczi, Marinella 1999. "L'interrogazione in sardo / Preguntai in sadru". In: Romanistik in Geschichte und Gegenwart 5: 101-112.

Mensching, Guido 2008. "Syntaktische Anmerkungen zur Informationsstruktur und zum Satzmodus im Sardischen”. Paper presented at the GGS Workshop, ZAS, Berlin, May, 1st-3rd, 2008.

Mensching, Guido 2012a. "Anmerkungen zur sardischen Syntax anhand des Vivaio Acustico delle Lingue e dei Dialetti d'Italia (VIVALDI)". In: Carola Köhler and Fabio Tosques (eds), (Das) DISKRETE TATENBUCH. Digitale Festschrift für DIETER KATTENBUSCH zum 60. Geburtstag, Berlin: Humboldt Universität.

[http://www2.hu-berlin.de/festschrift-kattenbusch/mensching-sardischsyntax.html, last consulted on Sept. 13th, 2015] .

Mensching, Guido 2012b. "Old Romance word order: a comparative minimalist analysis". In: Charlotte Galves, Sonia Cyrino, and Ruth Lopes (eds): Parameter Theory and Language Change, Oxford University Press, 21-42.

Mensching, Guido (in press). "Morfosintassi: Sincronia." In: Eduardo Blasco Ferrer, Peter Koch and Daniela Marzo (eds): Manuale di linguistica sarda. Berlin/New York: De Gruyter (= Manuals of Romance Linguistics).

Mensching, Guido and Eva-Maria Remberger 2010a. "La periferia sinistra romanza: topicalizzazione, focalizzazione e interrogazione in sardo". In: Maria Iliescu (ed.): Actes du XXVe Congrès International de Linguistique et de Philologie Romanes, Innsbruck, 3-8 septembre 2007, 7 vols, Tübingen, vol. 7, 189-197.

Mensching, Guido and Eva-Maria Remberger 2010b. "The Left Periphery in Sardinian”. In: Roberta D’Alessandro, Adam Ledgeway, and Ian Roberts (eds): Syntactiv Variation: The Dialects of Italy, Cambridge: Cambridge University Press, 261-276.

Mensching, Guido and Eva-Maria Remberger (in press). "Sardinian." In: Adam Ledgeway and Martin Maiden (eds): Oxford Guide to the Romance Languages (OGRL), Oxford: Oxford University Press.

Müller, Gereon 1998. Incomplete Category Fronting. A Derivational Approach to Remnant Movement in German. Dordrecht/Boston/London: Kluwer (= Studies in Natural Language and Linguistic Theory 42).

Nilsenova, Marie and Robert van Rooym 2003. "On Polar Questions.” Paper presented at SALT 13, Washington, May 9th-11th, 2003.

Obenauer, Hans-Georg 2004. "Nonstandard wh-questions and alternative checkers in Pagotto". In: Horst Lohnstein and Susanne Trissler (eds): Syntax and Semantics 
of the Left Periphery, Interface Explorations 9. Berlin, New York: Mouton de Gruyter, 343-384.

Obenauer, Hans-Georg 2006. "Special Interrogatives - Left Periphery, Wh-Doubling, and (Apparently) Optional Elements". In: Jenny Doetjes and Paz Gonzalves (eds): Romance Languages and Linguistic Theory 2004 - Selected Papers from 'Going Romance 2004', Amsterdam/Philadelphia: John Benjamins. 247-273.

Padovan, Andrea and Nicoletta Penello (eds.) 2006. Osservazioni sul sardo. Monographic issue of Quaderni di lavoro ASIt 6. [http://asit.maldura.unipd.it /papers.html, last consulted on March 11th, 2015]

Prieto, Pilar and Gemma Rigau 2007. "The Syntax-Prosody Interface: Catalan interrogative sentences headed by que". In: Journal of Portuguese Linguistics 6, 29-60.

Puddu, Mario 2000. Ditzionàriu de sa limba e de sa cultura sarda. Cagliari: Condaghes.

Puskás, Genoveva 2000. "Word Order in Hungarian: the Syntax of A' positions". Amsterdam: John Benjamins (= Linguistik Aktuell /Linguistics Today 33). http://dx.doi.org/10.1075/la.33

RAS 2006 = Regione Autonoma della Sardegna 2006. Limba Sarda Comuna. Norme linguistiche di riferimento a carattere sperimentale per la lingua scritta dell'Amministrazione regionale [http://www.regione.sardegna.it/documenti/1_72_20060418160308.pdf, last consulted on April 27 $\left.{ }^{\text {th }}, 2015\right]$.

Remberger, Eva-Maria 2010. "Left peripheral interactions in Sardinian." In: Lingua 120, 555-581. [Special Issue: Grohmann, Kleanthes K. \& IanthiMaria Tsimpli (eds): Exploring the Left Periphery]. http://dx.doi.org/10.1016/j.lingua.2008.10.010

Rizzi, Luigi 1997. "The fine structure of the left periphery." In: Liliane Haegeman, (ed.): Elements of Grammar: Handbook in Generative Syntax. Dordrecht: Kluwer, 281-337.

Rizzi, Luigi 2001. "On the position 'Int(errogative)' in the left periphery of the clause". In: Guglielmo Cinque and Giampaolo Salvi (eds): Current Studies in Italian Linguistics Offered to Lorenzo Renzi, Dordrecht: Foris, 287-296.

Rooth, Mats 1992. "A theory of focus interpretation". In: Natural Language Semantics 1: $75-116$. http://dx.doi.org/10.1007/BF02342617

Siemund, Peter 2001. "Interrogative constructions". In: Martin Haspelmath, Ekkehard König, Wulf Oesterreicher, and Wolfgang Raible (eds): Language Typology and Language Universals, vol. 2, Berlin, New York: de Gruyter, 1010-1028.

Vanrell, María del Mar, Francesc Ballone, Carlo Schirru and Pilar Prieto 2014. "Intonation and its interfaces in Sardinian polar questions". In: Loquens 1 http://dx.doi.org/10.3989/loquens.2014.01

Virdis, Maurizio 1988. "Sardisch: Areallinguistik". In Günter Holtus, Michael Metzeltin, and Christian Schmitt (eds), Lexikon der romanistischen Linguistik, Tübingen: Niemeyer, vol. 4, 897-913.

Wikberg, Kay 1975. "Yes-No Questions and Answers in Shakespeare's Plays. A Study in Text Linguistics". Åbo (Finland): Åbo Akademi (=Acta Academiae Aboensis, Ser. A. Humaniora 51).

Zubizarreta, María Luisa 1998. Prosody, focus, and word order. Cambridge Mass.: MIT Press. 